\title{
Three Decades of IP
Markets in Canada: Evolution, Risk and Return
}

CÉCILE CARPENTIER JEAN-MARC SURET 


\title{
2018s-04
}

\section{Three Decades of IPO Markets in Canada: Evolution, Risk and Return}

\author{
Cécile Carpentier, Jean-Marc Suret
}

\begin{tabular}{c}
\hline Série Scientifique \\
Scientific Series
\end{tabular}

\author{
Montréal \\ Mars/March 2018
}

(C) 2018 Cécile Carpentier, Jean-Marc Suret. Tous droits réservés. All rights reserved. Reproduction partielle permise avec citation du document source, incluant la notice $\mathbb{C}$. Short sections may be quoted without explicit

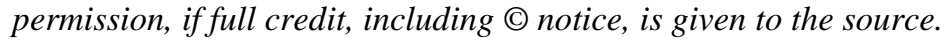

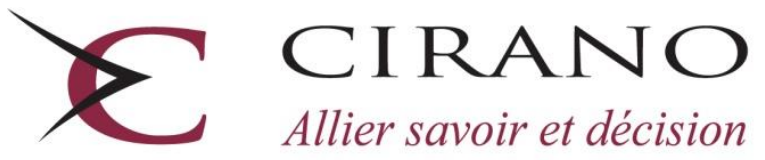

Centre interuniversitaire de recherche en analyse des organisations 


\section{CIRANO}

Le CIRANO est un organisme sans but lucratif constitué en vertu de la Loi des compagnies du Québec. Le financement de son infrastructure et de ses activités de recherche provient des cotisations de ses organisations-membres, d'une subvention d'infrastructure du gouvernement du Québec, de même que des subventions et mandats obtenus par ses équipes de recherche.

CIRANO is a private non-profit organization incorporated under the Quebec Companies Act. Its infrastructure and research activities are funded through fees paid by member organizations, an infrastructure grant from the government of Quebec, and grants and research mandates obtained by its research teams.

\section{Les partenaires du CIRANO}

\section{Partenaires corporatifs}

Autorité des marchés financiers

Banque de développement du Canada

Banque du Canada

Banque Laurentienne

Banque Nationale du Canada

Bell Canada

BMO Groupe financier

Caisse de dépôt et placement du Québec

Énergir

Hydro-Québec

Innovation, Sciences et Développement économique Canada

Intact Assurance

Investissements PSP

Ministère de l'Économie, de la Science et de l'Innovation

Ministère des Finances du Québec

Mouvement Desjardins

Power Corporation du Canada

Rio Tinto

Ville de Montréal

Partenaires universitaires

École de technologie supérieure

HEC Montréal

Institut national de la recherche scientifique

Polytechnique Montréal

Université Concordia

Université de Montréal

Université de Sherbrooke

Université du Québec

Université du Québec à Montréal

Université Laval

Université McGill

Le CIRANO collabore avec de nombreux centres et chaires de recherche universitaires dont on peut consulter la liste sur son site web.

Les cahiers de la série scientifique (CS) visent à rendre accessibles des résultats de recherche effectuée au CIRANO afin de susciter échanges et commentaires. Ces cahiers sont écrits dans le style des publications scientifiques. Les idées et les opinions émises sont sous l'unique responsabilité des auteurs et ne représentent pas nécessairement les positions du CIRANO ou de ses partenaires.

This paper presents research carried out at CIRANO and aims at encouraging discussion and comment. The observations and viewpoints expressed are the sole responsibility of the authors. They do not necessarily represent positions of CIRANO or its partners. 


\title{
Three Decades of IPO Markets in Canada: Evolution, Risk and Return
}

\author{
Cécile Carpentier, Jean-Marc Suret*
}

\begin{abstract}
Résumé/Abstract
In Canada, initial public offerings (IPOs) have decreased sharply over the past twenty years, inducing potentially substantial negative effects on the economy. The reasons for this decrease are controversial. To contribute to the debate, we analyze the Canadian IPO market over three decades (1986-2016). First we illustrate its specificities using IPOs on the main and the venture stock exchanges and using other junior markets a benchmark. We discuss the evolution of the IPOs, which differs considerably between natural resource and non-natural resource firms. We then provide empirical evidence based on 2,145 Canadian IPOs. On average, these IPOs generate three-year negative abnormal returns, and more than $70 \%$ report negative abnormal returns. Large issuers reporting profits constitute the only subsample that provides fair returns, but they account for less than 5\% of IPOs. We observe a high level of skewness of abnormal returns, consistent with the behavioral finance proposition that investors are often unduly optimistic when valuing lottery stocks. The lemon market characteristics of the Canadian IPO market can probably explain why it is vanishing.
\end{abstract}

\footnotetext{
* Cécile Carpentier and Jean-Marc Suret are professors at the School of Accounting at Laval University, and CIRANO Fellows; e-mail: cecile.carpentier@fsa.ulaval.ca and jeanmarc.suret@,fsa.ulaval.ca. Cécile Carpentier (corresponding author): Laval University, Faculty of Administrative Science, School of Accounting, 2539 Pavilion Palasis-Prince, G1V 0A6, Québec, Canada, Phone: (418) 656-2131 \#6385. The authors thank the Fonds pour l'éducation et la saine gouvernance de l'Autorité des marchés financiers du Québec (“Autorité") for financial support. The authors assume full responsibility for any errors remaining in the text. The views expressed in this article are those of the authors, and do not necessarily reflect the position of the Autorité.
} 


\section{INTRODUCTION}

Initial Public Offerings (IPOs) are important events for firms and the economy. They are a pivotal step in company development that enable innovative high-growth firms to generate new jobs and revenues (Weild and Kim 2009). In Canada, IPOs have decreased sharply since the early 1990s (Magnan and Campbell 2014, Tingle et al. 2014); this is particularly alarming because of the decline in the number of listed companies. ${ }^{1}$ The decrease in IPOs is concomitant with the rise in acquisitions of the most promising firms by large foreign companies (Tingle et al. 2014), including acquisitions of venture capital (VC)-backed firms (Carpentier and Suret 2014). Studies of this IPO market are scarce, generally old, and restricted to the main market, the Toronto Stock Exchange (TSX). To our knowledge, no long-run detailed analysis of the asserted Canadian IPO decline has been conducted. This is partly why, according to Tingle et al. (2014), ${ }^{2}$ the collapse of the Canadian IPO market remains hard to explain. This explanatory paper attempts to fill this gap.

The first contribution of this paper is that it analyzes IPOs over the last 30 years by stock exchange, decade and industry. We compare the main characteristics of the Canadian market with similar stock exchanges to illustrate its specificities; this constitutes our second contribution. In addition, we discuss the implications of these specificities. Essentially, investors face high information asymmetry on early-stage IPO markets. Low listing requirements and high asymmetry favour the development of a lemon market that results in most of the firms listed being of low quality (Mahoney 1995, Black 2001, La Porta et al. 2006). Ultimately, a lemon market should disappear, except if investors depart from rational behaviour. We assess the quality of Canadian IPOs by analyzing long-run performance and the distribution of abnormal returns. We try to determine to what extent the evolution of IPOs' characteristics is associated with changes in the IPOs' performance. This represents our third contribution. We then summarize the asserted reasons for the IPOs' decline, including the disappointment proposition. Following Leleux and Muzyka (1997), we suggest that the poor returns of the 1980s and 1990s might have reduced investors'

\footnotetext{
${ }^{1}$ D. Hasselback, The amazing disappearance of the Canadian Public Company, Financial Post, May 30, 2016: "Since 2007, the number of publicly listed companies in Canada has dropped 16.7 per cent, according to statistics from TMX Group Ltd." http://business.financialpost.com/news/fp-street/the-amazingdisappearance-of-the-canadian-public-company

${ }^{2}$ B. C. Tingle, Canada's collapsing IPO markets hard to explain, Special to Financial Post, September 4, 2014, http://business.financialpost.com/opinion/canadas-collapsing-ipo-markets-hard-to-explain
} 
appetite for small IPOs of emerging firms. We also discuss the recommandations made to revitalize the IPO market in Canada. This is our fourth contribution.

Our main results are as follows. First, since 1986, we observe a stronger decrease in IPOs on the TSX venture exchange (TSXV) than on the TSX, largely driven by a strong reduction in the number of non-natural resources (non-NR) issuers. However, on the TSX, the annual average number of IPOs reported between 1970 and 1985 by previous studies is lower than that reported since 2006. The asserted IPO decline is grounded in the voluminous, albeit temporary, activity observed at the end of the 1980s. We note a strong increase in the median size of the issues. From 2006 to 2016, TSX issuers raised $\$ 1,761$ million per year. This is more than the $\$ 1,229$ million per year raised from 1986 to 1995. Second, in Canada, the low listing requirements have allowed very small firms to list at an early development stage: $88.76 \%$ of IPO firms report losses before listing and $72.38 \%$ have no revenues. As a result, this market cannot be compared with those of other developed countries. Such a situation fits the conditions for the development of a lemon market, which attracts low-quality firms. Third, we report significant negative post-listing abnormal returns, except for the large profitable issuers, which make up less than $5 \%$ of the sample. Returns are more negative on the TSXV than on the TSX, and value-weighted abnormal returns surpass equally weighted abnormal returns, indicating that, in each group, larger firms perform better than smaller ones. Returns are positively linked to the firms' development stage. Probably owing to the sharp increase in issue size, the abnormal returns on the TSX became positive starting in 2006. Fourth, we observe a significant level of skewness in the abnormal return distribution, consistent with the hypothesis that most Canadian stocks are lottery stocks, a situation that can explain the involvement of individual investors in a market characterized by poor returns.

Leleux and Muzyka (1997) attempt to explain why so few IPOs list on the European junior markets. They suggest that insufficient investor interest, driven by long-term underperformance following past IPOs, could have contributed to the lack of demand. We posit that the poor performance of Canadian IPOs from 1986 to 2005 could partially explain the decrease in number and increase in size of non-NR IPOs that we report. Our observations are consistent with an increasing lack of investor interest in smaller issues. For NR firms, the evolution is more complex because the commodity prices probably influence the number of IPOs and their returns. 
Part 1 presents the specificities of the Canadian IPO market, reviews previous works and develops our propositions. Part 2 describes the data and empirical methods. Part 3 specifies the results. The implications are discussed in Part 4, which concludes the paper.

\section{SPECIFICITIES OF THE CANADIAN IPO MARKET}

The Canadian market is distinctive regarding several dimensions, including the split between two stock exchanges and the fact that about half of IPOs come from NR firms. There is no previous evidence regarding the evolution of the market along these dimensions. We first analyze the Canadian market from 1986 to 2016 and compare it with other markets to affirm its specificities. We then discuss the implications of this situation and derive propositions.

\subsection{Data}

We collected the lists of Canadian IPOs from FPInfomart.ca from 1993 to 2016 and hand-collected the data from the Financial Post's paper publications (Record of new issues, cumulative report) from 1986 to 1992. Data for the previous years are difficult to access because there is a lack of systematic and detailed records by the predecessors of the TSXV. We exclude issues of capital pool companies, income trusts, investment funds and structured products. ${ }^{3}$ We delete eight privatizations of state-owned companies and five demutualizations of insurance companies because they constitute a simple change in the firm's statute. ${ }^{4}$ We exclude 14 firms that list only on a foreign exchange because they are not Canadian IPOs. We obtained accounting data from Sedar, Mergent online and the IPO prospectuses. Before 1997, when SEDAR was unavailable, we got the prospectuses from securities regulators, investment bankers, and academic libraries in several provinces.

\footnotetext{
${ }^{3}$ This is particularly important in Canada because trust units' IPOs are not only more numerous than corporate offerings, but they are also much larger owing to the many IPOs of exchange-traded funds (ETFs), closed-end funds and special-purpose acquisition companies (SPACs), which Maclean calls "Frankenstocks." These Frankenstocks constitute a growing proportion of IPOs. See J. Kirby: Public companies in Canada are going the way of the Dodo, Maclean's, August 2, 2016: http://www.macleans.ca/economy/economicanalysis/public-companies-in-canada-are-going-the-way-ofthe-dodo/

${ }^{4}$ These operations are atypical (GP can exceed $\$ 1$ billion) and are conducted for reasons other than financing companies' growth. Boardman et al. (2002) show that Canadian privatizations made using IPOs significantly improved the operating and financial performance of firms, and that in the five years following privatization, shareholders enjoyed significant positive abnormal returns.
} 


\subsection{IPO characteristics}

Table 1 presents the number and main characteristics of Canadian TSX and TSXV ${ }^{5}$ IPOs from 1986 to 2016. The TSX and the TSXV constitute distinct universes, although the two markets partly overlap. ${ }^{6}$ They mainly differ by the issue size: the median gross proceeds (GP) are $\$ 0.61$ million on the TSXV and \$27.55 million on the TSX. The number of IPOs has decreased fourfold on the TSXV between the beginning and the end of our study period but only twofold on the TSX.

Because NR and non-NR firms differ, we report the statistics for each category in Table 2. The median NR GP are $\$ 0.67$ million for the whole period and \$1.60 million from 2006 to 2016. ${ }^{7}$ For non-NR firms the median GP increase from $\$ 1.21$ million to $\$ 40$ million. As observed in the US (Gao et al. 2013, Rose and Davidoff 2016), the strong decrease in the number of small IPOs drives the evolution of the IPO market in Canada. Moreover, the decrease in IPOs is stronger for non-NR firms. From 2006 to 2016, non-NR IPOs represent 12.93\% of IPOs from 1986 to 1996. Table 2 illustrates the steady decrease. It begins in 2001, when the annual average number of non-NR IPOs falls from about 70 to less than 20 . The second step in the decrease begins in 2008, when the annual average falls below 8. From 2006 to 2016, NR IPOs represent 53.29\% of the IPOs observed at the beginning of the period. The strong decrease in small IPOs of non-NR firms mostly explains the Canadian IPOs' decline.

More than $74 \%$ of IPO firms report losses; this proportion reaches $89.54 \%$ for NR issuers. This proportion increased from $89.34 \%$ before 1996 to $94.42 \%$ in the last decade, when IPOs of profitable NR firms became exceptional. For non-NR issuers, the proportion is $58.71 \%$, close to the 54\% reported in the US from 2000 to 2016 (Ritter 2016 p.28), and it increased from 57.05\% in the first decade to $68.14 \%$ after 2006 .

Insert Tables 1 and 2 here

\subsection{Canadian IPO market: specificities and comparisons}

\footnotetext{
${ }^{5}$ We combined IPOs launched on the TSXV and on its predecessor, the CNDX, and those launched on the Canadian Securities Exchange (CSE) operated by CNSX Markets Inc.

${ }^{6}$ In December 2001, in the middle of our period of analysis, we rank the market capitalization of all Canadian Stocks. Using \$25 million as a cutting point, we estimate that 374 stocks listed on the main board fail to reach this limit, while 52 firms listed on the junior market exceed this threshold.

${ }^{7}$ In 2014, the median GP of NR IPOs are $\$ 100.16$ million, which constitutes an anomaly due to the small number of issues.
} 


\subsubsection{A market of micro and nanocap stocks}

Most Canadian IPOs are made by small firms that issue micro or nanocap stocks. ${ }^{8}$ As illustrated in Table 1, over the three decades the median GP are \$1.04 million. Median GP reach \$27.55 million on the TSX but are only $\$ 0.61$ million on the TSXV. The TSXV differs strongly from other junior (or SME) markets that list small firms. In Europe, the average GP range from $\$ 13.15$ million to $\$ 66.81$ million depending on the type of junior market. On the AIM, the mean (median) GP are \$22.58 (\$10.67) (Vismara et al. 2012, Pandes and Robinson 2013 p.129). The average GP are \$20.15 million on the JSE Alt X in Japan and \$15.78 million on the Taipei Exchange (Harwood and Konidaris 2015). According to the World Federation of Exchanges, at the end of 2014 the average TSXV market capitalization was $\$ 11.49$ million, versus $\$ 117.06$ million for the AIM and $\$ 1,006$ million on ChiNext, the Chinese junior market. Only the Nigerian Stock Exchange, New Connect in Poland and NILEX in Egypt report lower average market capitalization than the TSXV (WFE 2016).

TSX IPOs are also comparable to those observed on junior markets. From 1993 to 2016, only 110 IPOs had a GP higher than $\$ 100$ million, and except for the most recent decade, the median GP on the TSX are in the same range as those reported above for European junior markets. From 2000 to 2016, the median (average) GP of US IPOs are about US\$100 (229) million (Ritter 2016 p.26), and a firm that lists on a major exchange with a capitalization of less than US\$75 million is considered a small capitalization company (Rose and Davidoff 2016). Globally, the Canadian IPO market comprises very small firms according to international standards.

\subsubsection{A market of early-stage firms}

New ventures' development comprises several stages. In the seed stage, the entrepreneur has a concept for a potentially profitable business opportunity, which still has to be developed, and the firm reports no revenues. Such firms present huge valuation challenges because they lack the classic value drivers. Moreover, information asymmetry is high, and seed financing is generally left to specialized investors. Even business angels seem reluctant to invest at a pre-revenue stage (Carpentier and Suret 2015a). A second development stage begins with getting the first revenue

\footnotetext{
${ }^{8}$ The SEC states that the term "microcap stock" applies to companies with a market capitalization of less than US\$250 or US\$300 million. The smallest public companies, with market capitalization of less than US\$50 million, are "nanocap stocks." https://www.sec.gov/investor/pubs/microcapstock.htm
} 
and ends with reaching profitability. Profitability signals the long-term economic viability of the firm and reduces the firm's dependency on external financing. Accordingly, getting the first revenues and becoming profitable constitutes the classic milestone of new venture development (Davidsson and Honig 2003, Jain et al. 2008).

Later development stages are generally associated with an increase in revenues, profitability, and total assets. Table 1 and 2 clearly indicate that in Canada, most IPOs are made by firms at seed or early development stages. This contrasts with other markets. For example, even if the proportion of loss firms has increased in the US, the NASDAQ demands revenue, except for firms with a market capitalization higher than US\$160 million. On the AIM, pre-IPO average revenues are around $\$ 12.35$ million, and the minimum reported revenue is $\$ 1.79$ million (Espenlaub et al. 2012).

\subsubsection{NR and evolution}

We depict the evolution of Canadian IPOs in figures 1 and 2. In figure 1, we include the pre-1986 data reported in Suret and Cormier (1997, Table 9) and Jog (1997, Table 4) for the TSX, and report the evolution for the TSX, the TSXV and non-NR IPOs. This figure illustrates the very strong decrease in TSXV IPOs and in non-NR IPOs. On the TSX, a strong decrease is evident only since 2012. The number of TSX IPOs before 1986, as reported in previous studies (Jog 1997, Suret and Cormier 1997), mitigates the asserted decrease in IPOs. The 186 reported IPOs from 1971 to 1985 indicate an annual average of 12.40 IPOs, which is lower than the annual average of 14.45 IPOs estimated from 2006 to 2016 after the asserted decrease in IPOs. ${ }^{9}$ The anomaly in the number of IPOs since 1970 is probably more attributable to the huge number of issues in the mid-1980s and the mid-1990s than to the decrease observed after that time. The tax incentives implemented in Quebec (the Quebec Stock Saving Plan, or QSSP) partially explain this intensive activity.

The evolution of NR prices may explain the changes observed in the Canadian IPO market, where half of the issuers are involved in the NR sector. In Figure 2, we illustrate the evolution of NR IPOs with the oil price index and the commodity index for metal from 1986 to $2016 .{ }^{10}$ Up to the

\footnotetext{
${ }^{9}$ Previous studies do not mention the exclusion of IPOs of financial products. The reported numbers from 1970 to 1985 probably overstate the number of IPOs as estimated in the present study.

10 The Commodity price index is a Producer Price Index by Commodity for Metals and Metal Products, from https://fred.stlouisfed.org. The Oil price index is based on Cushing, OK WTI Spot Price FOB (Dollars per Barrel) from https://www.eia.gov/dnav/pet/hist/LeafHandler.ashx?n=PET\&s=RWTC\&f=A.
} 
beginning of the 2000s there is no apparent connection between the small changes in NR prices and the number of IPOs. The strong decrease in NR IPOs occurs from 1988 to 1992, when the commodity prices remain unchanged and the oil price increases slightly. In recent years, the number of IPOs seems to follow the changes in the oil price index more closely. The sharp decrease from 2013 to 2016 is probably associated with the low oil price index, and the increase in IPOs from 2005 to 2008 is a probable consequence of the increase in the oil price index. Overall, the changes in NR indices cannot explain the 30-year evolution of the Canadian IPO market.

The evolution of the Canadian IPO market is also characterized by an increase in issue size. On the TSX, during the last decade the average (median) GP reached $\$ 121.85$ (\$50) million. The corresponding number is $\$ 40.44$ (\$16.59) million from 1986 to 1995 . On the TSXV, we also observe that the average and median GP rose threefold between the first and the last decade, but both values remain low. Because TSXV IPOs are more numerous than TSX IPOs, the median GP on both markets remain as low as $\$ 2.40$ million in the most recent decade.

Insert figures 1 and 2 here

2.3.4 Venture capitalists and institutional investors

Venture capitalists (VCs) and institutional investors are considered to be reputable intermediaries who improve market quality through a certification effect. VCs are not significantly involved in the Canadian IPO market, as illustrated in Table 3. In the US, VCs have backed $39.37 \%$ of IPOs since 1986, and this proportion reaches 50\% when we consider the other types of financial sponsors grouped with VCs, like private equity funds (Ritter 2016). In Canada, from the successive editions of the Canadian VC Association report, we detect 176 VC-backed IPOs from 1986 to 2016, which represent $5.80 \%$ of IPOs and $11.86 \%$ of non-NR IPOs. Moreover, one-third of the VC-backed IPOs in Canada are clustered between 1997 to 2000, namely during the Internet bubble.

\section{Insert Table 3 here}

In the US, institutional investors play a significant role in IPOs, and institutional ownership is significantly and positively linked to post-IPO performance (Field and Lowry 2009). In Europe, most of the IPOs on the exchange-regulated markets are offered to institutional investors exclusively (Vismara et al. 2012). In contrast, institutional investors are not heavily involved in the IPO market in Canada, especially in junior IPOs (Pandes and Robinson 2013). In this country, the 
National Instrument 81-102: Investment Funds prevents funds from owning more than $10 \%$ of a firm. For an IPO of $\$ 4$ million, typical of the TSXV, the maximum investment is $\$ 400,000$. The costs associated with selecting, monitoring and trading in micro capitalizations generally prevent institutional investors from investing in small IPOs with a float corresponding to a few million dollars. The analysis of institutional investors' involvement in Canadian IPOs falls out of the scope of this study. An accurate database is lacking, and the data should be hand-collected. However, we conduct the following experiment. We select the largest and most successful non-NR TSXV firms based on their graduation on the TSX, from 1997 to 2015 (209 cases). We contend that these cases are those where the probability of observing institutional involvement is highest. Based on handcollected information, we detected 60 cases $(28.71 \%)$ where institutional investors were involved at graduation time. According to Carpentier et al. (2010), these success stories constitute about 7\% of newly listed firms on the TSXV and occur about 5 years after the initial listing. This partial experiment shows that VCs seem to be involved in only about $2 \%$ of new listings on the TSXV, 5 years after their IPOs.

\subsection{Implications and previous evidence}

\subsubsection{Implications for the market}

More than half of Canadian IPOs are made by firms without revenues and with minimal capitalization. Investors thus face firms with no track record and very limited information to estimate future prospects. Moreover, reputational intermediaries are only marginally involved in this market. This creates the conditions of a lemon market.

A critical barrier that stands between issuers of common shares and individual investors is asymmetric information (Black 2001). The value of a firm's shares depends on future cash flows; past performance, revenues and profitability are important signs of future prospects. When a firm has no history, no record of profitability and even no revenues, past performance can hardly provide guidance to assess future cash flows, and information asymmetry is very high. The rise in the proportion of IPOs firms reporting no revenues or losses (Table 1) may have increased this asymmetry. High information asymmetry induces opportunistic behaviour in entrepreneurs. As Black (2001) explains, insiders have an incentive to exaggerate the issuer's performance and prospects. The typical individual investors cannot directly verify the information and cannot rely on the company's prior reputation. This is why investing in early-stage firms is generally done by 
specialized investors, who are able to deal with information asymmetry and its consequences (Amit et al. 1998). This problem is especially serious for small companies that sell shares to the public for the first time. The entrepreneurs have incentives to offer bad or overvalued projects. According to the framework developed by Akerlof (1970), because they cannot discriminate between the projects, investors will offer low prices that reflect the average low quality of issues. This induces the managers of good firms to choose alternatives like private placements or acquisitions. As Black (2001, p.786) argues: "Securities markets are a vivid example of a market for lemons." Strong regulation and high level of listing requirements is a prerequisite for the establishment of a sound equity market (Black 2001, La Porta et al. 2006).

According to this pattern, when listing requirements are low, the IPO market mainly attracts low quality firms and provides disappointing returns. Firm quality will probably decrease, and ultimately this market will disappear if investors are rational. Rose and Davidoff (2016) observe that small listed companies generally fail to grow, and remain in the small capitalization category. They conclude that the IPOs' decline appears to be due to the historical unsuitability of small firms for the public market.

\subsubsection{Implications for investors}

Securities regulation relies on the assumption that investors are rational and can make adequate decisions when relevant information is available. However, individual investors' decision process seems far from rational (Langevoort 2002, Choi and Pritchard 2003, Choi 2006). The departure from rational decision making is greater when valuation uncertainty is higher and stocks are more difficult to value (Kumar 2009a). This is clearly the case for small IPOs with no track record, negative earnings and limited information (Xiao and Yung 2015). Like lottery tickets, they provide mostly losses but also large returns in a small number of cases (Barberis and Huang 2009, Kumar 2009b, Lepone and Wright 2014). In contrast to the prediction of a standard expected utility model, individuals who face such prospects seem to exhibit a preference for skewness: they tend to place high subjective valuations on large but low probability gains, which leads to a preference for gambles with highly right-skewed payoffs (Kahneman and Tversky 1979). This leads them to overvalue stocks that provide losses in most cases, and very rarely large gains. If positively skewed securities are overpriced, they will offer a negative average abnormal return. According to Barberis 
and Huang (2009), the preference for skewness is a potential explanation for low average return on IPOs and private equity.

Kumar (2009a) asserts that the characteristics of lottery stocks include a low issue price, small capitalization, lack of analyst coverage, limited institutional investor involvement, and low liquidity. ${ }^{11}$ These characteristics perfectly fit the group of small IPOs that list at a pre-revenue stage. The large information asymmetry surrounding such firms also favours the departure from rational decision-making. The information asymmetry is partly solved when firms begin to collect revenues, and when they make profits. More rational pricing and a lesser preference for skewness are likely to prevail for large IPOs, with which institutional investors may be involved.

\subsubsection{Propositions}

According to the explanatory character of this paper, we do not attempt to test a formal hypothesis. If the Canadian IPO market can be compared to a lemon market, the quality of newly listed firms should be low, on average. This should not be a concern if investors are skilled and rational, and can appraise new issues at their intrinsic value. However, individual investors constitute the main actors in the Canadian IPO market. These investors are generally unskilled at appraising and adequately monitoring emerging firms that are not profitable or are at a pre-revenue stage. As Giudici and Roosenboom (2004b) maintain, stock market financing lacks the typical provisions such as active monitoring and covenants that VCs implement to protect their investments from information asymmetry and entrepreneur opportunism. Allowing relatively uninformed small investors to invest in highly risky entrepreneurial ventures may increase the chances that such investors will lose considerable sums of money (Chemmanur and Fulghieri 2014). The preference for skewness is likely to increase the overvaluation of new issues, leading to a negative return. Based on the observations above, we will test the following propositions.

Proposition 1: The average abnormal return of Canadian IPOs is significantly negative.

\footnotetext{
${ }^{11}$ From 1996 to 2004, the average market capitalization of Canadian firms followed by financial analysts was $\$ 1.6$ billion, and the smallest firms exhibited an average market cap of $\$ 457$ million (Dutta et al. 2008). In the US, according to S. Luparello, Director, Division of Trading and Markets, SEC, institutional investors are only marginally involved (10.9\%) in companies with less than US\$50 million (83\% for largest firms) https://www.sec.gov/news/testimony/testimony-venture-exchanges.html.
} 
Investing wisely in pre-revenue stage emerging firms demands more skills and tools than does investing in more mature firms. Valuation mistakes are more likely when the information is limited, as in the case of firms at an early development stage. The lemon market hypothesis suggests that, in a context of very large information asymmetry, the incentive for entrepreneurs to sell overvalued stocks becomes huge (Mahoney 1995). Unskilled investors are unable to detect such overvalued stocks, which leads to the lemon problem: entrepreneurs essentially offer bad projects when asymmetry is large and regulation lenient (Black 2001). This is consistent with the high failure rate of companies at a pre-revenue stage. Individual investors lack the tools and abilities to correctly appraise such investments, which share many characteristics of private equity investment (Fenn et al. 1997). Hence, the analysis of abnormal returns should indicate that:

Proposition 2: The average abnormal return of Canadian IPOs is lower for firms at an early development stage than for more mature firms.

A lemon market is likely to disappear, except if investors persistently buy stocks with negative expected returns. This would occur if they exhibit a preference for skewness and if they face lottery stocks. Accordingly:

Proposition 3: The distribution of post-IPO abnormal returns of Canadian firms is highly skewed.

\subsubsection{Previous evidence}

Empirical evidence of the long-run performance of Canadian IPOs is scarce. Based on TSX data from 1971 to 1995, Jog (1997) reports that three (four) years after issue, Canadian IPOs lagged $41.02 \%$ (48.37\%) behind the main market index. Ursel (2000) studies a sample of 30 large IPOs on the TSX for the period 1997-1999, that underperform the TSE Index by only 3\%. Kooli and Suret (2004) examine 445 Canadian IPOs from 1991 to 1998 on the TSX and the predecessors of the TSXV. They provide evidence that small IPOs with GP lower than \$10 million underperform significantly (-44.86\%) after five years, while larger IPOs provide returns in line with a similar investment in the control firms. Smithson and Firer (2007) analyze new mining listings from 1997 to 2006 on the TSX and the AIM. On the Canadian market, they observe significant losses relative to the market index of $-64.50 \%$ after three years, but they do not report underperformance on the AIM. Carpentier et al. (2010) find that an aggregate index of TSXV IPOs exhibits the same return as the S\&P/TSX composite index (S\&P/TSX index) from 1986 to 2006, but they do not estimate abnormal returns. Magnan and Campbell (2014) report abnormal negative returns for TSX 
Canadian IPOs from 2003 to 2012, for one- and two-year horizons. To summarize, our knowledge of the aftermarket performance of Canadian IPOs is incomplete, based on various methodologies and benchmarks. The effect on performance of the firm's size, development level, and sector, is limited. Further, the previous works predominantly focus on the TSX.

On main markets, IPOs provide, on average, negative abnormal returns (Jenkinson and Ljungqvist 2001). The subsample of small high-growth firms that invest more than mature companies explains most of this underperformance (Eckbo and Norli 2005). Small IPOs are rare events in the US: only one study of 251 penny stocks from 1990 to 1998 (among 2,958 IPOs) reports a three-year abnormal return lower than $-100 \%$ (Bradley et al. 2006). These penny stock IPOs have average GP of $\$ 7.46$ million, much higher than those observed on the TSXV.

The Canadian market is more comparable to junior markets. Studies of these markets report very low abnormal returns following IPOs, including the AIM (Goergen et al. 2003, Giudici and Roosenboom 2004a, Locke and Gupta 2008, Vismara et al. 2012, Gerakos et al. 2013). Gerakos et al. (2013) stress that IPOs on the AIM are of poorer quality than US pink sheet stocks. Consistent with the lemon market story, across the world, junior markets dedicated to emerging firms with weak listing requirements have failed or faced serious problems. Approximately 170 junior markets have been launched, but only 40 survive (Eberhart and Eesley 2017), and the World Bank asserts that only three of them can be considered as successes in developed countries, including the AIM and the TSXV (Harwood and Konidaris 2015). ${ }^{12}$ Schwartz (2017) argues for listing standards that eliminate the smallest and youngest firms.

\section{DATA AND METHODOLOGY}

\subsection{Market data sources}

We cannot analyze the IPO population because we need three years of data after the IPO to estimate the abnormal returns, and because much data are not available before the implementation of SEDAR in 1997. We restrict the sample to the years 1986 to 2012, and to issuers with accounting and market data. We get a sample of 2,145 IPOs, which includes more than $80 \%$ of the population. Market data come from Datastream. Using market data for Canadian IPOs is a real challenge. We

\footnotetext{
${ }^{12}$ According to the World Bank, the third success story is the Australian Securities Exchange (ASX). This
} is the main Australian market; ASX is not considered to be a junior market. 
observe that a large proportion of newly listed firms merge, aggregate, are acquired, delist, change name, or receive a cease trade order when they fail to meet disclosure requirements, or for other reasons. The database reports numerous truncated series of returns that cannot be ignored without creating a strong survival bias. To adjust the incomplete series of returns we hand-checked the status of each firm three years after the IPO. We first used the TSX and TSXV website to verify whether the issuer is still listed. For each of the delisted stocks, we identified the date, reason for and circumstances of delisting using the TSXV website, SEDAR, FPinfomart.ca, securities regulators' websites and Factiva. We examined each merger or acquisition to estimate the trade price, using the buyer stock price in the case of a share exchange. The latest return is set to $-100 \%$ when the firms delist for negative reasons, and we use the trade price for mergers and acquisitions.

\subsection{Issuer development stage}

We group the observations according to the revenues, profitability and size, following the practices that stock exchanges use to define listing requirements and the classical milestone used in entrepreneurial finance. Seed-stage issuers that report no revenues constitute GROUP1. A second group (GROUP2) is composed of early-stage firms that report revenues but negative earnings before non-recurring and extraordinary items. Stock exchanges' minimum listing requirements generally stipulate positive earnings. Valuation mistakes are frequent for loss-reporting firms, because investors seem unduly optimistic (Carpentier et al. 2017).

Profitable issuers can be micro caps or large firms. There is no clear definition of limit of size useful for the Canadian market. All Canadian IPOs are microcaps according to the US benchmark of US\$ 250 million. We use the pre-IPO book value of equity as a measure of size, and a cutting point of $\$ 25$ million (adjusted for inflation). Firms that reach this limit generally exhibit post-IPO market capitalization higher than $\$ 75$ million (US\$50 million). Accordingly, they are not considered as nanocap stocks. They would have been able to list on the NASDAQ capital market and to be included in the S\&P/TSXV index. ${ }^{13}$ Profitable firms below this threshold constitute GROUP3, and GROUP4 consists of the largest profitable firms.

${ }^{13}$ To be included in the S\&P/TSXV Composite index, a security must have a relative weight of at least $0.05 \%$ of the total capitalization, hence $\$ 50$ million in 1999. 
VCs are assumed to improve the performance of newly listed firms. Brav et al. (2000) assess that long-run IPO underperformance is concentrated among non-VC-backed firms and small firms with low book-to-market ratios. They contend that there is no general underperformance of IPO firms. Accordingly, we supplement our analysis by isolating VC-backed IPOs. Cycles in the IPO market influence the type, volume, fate and pricing of issues. We characterized Hot and Cold issue market periods following Helwege and Liang (2004), by estimating the 3-month centered moving average of the IPO number. DHOT (DCOLD) has a value of one if the corresponding month is in the upper (lower) third of the moving average distribution.

\subsection{Abnormal returns}

We estimate abnormal returns following IPOs using the buy-and-hold abnormal return (BHAR) method, the classical approach that consists of comparing the performance of portfolios composed of firms of each group (Ang and Zhang 2015). From 1997 to 2015, the S\&P/TSX index outperforms the BMO Small Cap unweighted index (BMO Small Cap) by about 292 basis points annually, indicating a strong reverse size effect. Accordingly, we use the two market indices as a benchmark. We use the issue price as a starting point to estimate the return, but we also provide the results when the starting point is the market price. On average, in numerous exchanges the market price is higher than the issue price; the difference between both prices is generally considered as the underpricing. Investors who can buy IPO stocks from investment bankers get the return based on the issue price. When they buy the stock on the secondary market shortly after the IPO, they get the return based on the market price.

We estimate BHAR from the issue price or from the beginning of the post-listing month (1) price to the month q (36):

$\overline{B H A R_{1 \text { to } q}}=\sum_{i=1}^{N q} w_{i, q} B H A R_{i, 1 \text { to } q}$

Where

$$
B H A R_{i, 1 \text { to } q}=\prod_{s=1}^{q}\left(1+R_{i, s}\right)-\prod_{s=1}^{q}\left(1+R_{b i, s}\right)
$$


Thus, BHARs measure the average multiyear returns from a strategy of investing in all issuing firms, and selling at the end of a particular holding period, versus a comparable strategy using the benchmark $\left(\mathrm{R}_{\mathrm{bi}}\right)$. We estimate equally weighted (EW) and value-weighted (VW) portfolio returns to override the influence of a small subsample of larger companies in VW returns. We base the tests of propositions 1 and 2 on statistical tests on the average three-year BHAR, a classic measure in this field. However, previous research has shown that several factors other than firm characteristics also influence post-listing performance. Hence, we supplement the analysis of average BHAR with a multivariate model that includes control variables and provides more robust empirical tests.

\subsection{Explaining abnormal returns}

We use the following robust regression model with Huber M-estimation:

$$
\begin{aligned}
& \text { BHAR }_{i}=\alpha_{1}+\alpha_{2} \text { LMcap }_{i}+\alpha_{3} \text { DNR }_{i}+\alpha_{4} \text { GROUP }_{i}+\alpha_{5} \text { GROUP }_{i}+\alpha_{6} \text { GROUP }_{i}+\alpha_{7} \text { DHOT }_{i}+ \\
& \alpha_{8} \text { DCOLD }_{i}+e_{i},
\end{aligned}
$$

where the dependent variable is the three-year abnormal return of each firm and the explanatory variables include the main characteristics of the issue and issuer. We estimate the abnormal returns using the market price. ${ }^{14}$ For the sake of brevity, we report only the results obtained with that price. However, our levels of significance of the various coefficients are insensitive to the choice of the beginning price. We include the dummy associated with GROUP1, GROUP2 and GROUP4. The reference group is consequently GROUP3, composed of firms that report positive earnings but shareholders' equity lower than $\$ 25$ million. ${ }^{15}$ We control for several variables generally considered to be related to post-IPO long-run performance. LMcap is the log of the post-IPO market capitalization. ${ }^{16}$ Based on SIC codes, we defined a dummy variable associated with NR IPOs (DNR), considering that the strong performance of the energy and mining sector can influence the returns. DHOT (DCOLD) has a value of 1 if the corresponding month is in the upper (lower)

\footnotetext{
${ }^{14} \mathrm{We}$ do not use daily data, which are often inaccurate following IPOs. The coverage of new small issues is not systematic during the first trading days. Moreover, trading on several IPOs begins several days or even weeks after the official issue date. For this reason, consistent with the global objective of the paper, we do not provide a detailed analysis of underpricing.

${ }^{15}$ We cannot include GROUP3 because our regression model is not full rank when all groups are included; this is because our classification system results in any one group being a linear combination of the other 3 . ${ }^{16} \mathrm{We}$ assess the robustness of the model to the size estimation by using the pre-IPO shareholders' equity and the same value increased by the GP. The (unreported) results are similar.
} 
third of the moving average distribution. We also controlled but do not report results for auditor prestige (including a dummy PAUDIT that takes the value 1 if the auditor is one of the big 5 or 4 ) and for the number of years since the incorporation of the firm (or since the founding date if the firm reincorporates prior to listing, AGE). These two variables are highly correlated with the other variables in the models, and they fail to play a significant role.

Given that the literature emphasizes the positive role of VCs at the IPO, we also modify the model in equation (5) to include a dummy variable for VC involvement (DVCBIPO). We carefully scanned the section devoted to the main shareholders in each prospectus to detect VC involvement. A dummy DVCBIPO is set to 1 for each firm where a VC is involved.

\section{RESUlts}

\subsection{Descriptive statistics}

In Table 4, we report the main statistics for the groups defined above for the whole sample (Panel A), non-VC backed IPOs (Panel B) and VC-backed IPOs (Panel C). GROUP1 firms report no revenues, and their median pre-IPO total assets are $\$ 0.39$ million. The median GP are very low, at $\$ 0.54$ million, and their post-IPO market capitalization is $\$ 3.31$ million. The firms in GROUP2 generally report low revenues. They report median revenues of $\$ 0.67$ million and post-IPO market capitalization of $\$ 14.10$ million. Together, seed and early-stage loss firms in GROUP1 and GROUP2 encompass $75 \%$ of Canadian IPOs of the last three decades, with a median market capitalization lower than $\$ 5$ million. Even in GROUP3, where firms report positive earnings, median revenues and capitalization are very low, according to international standards, at $\$ 9.40$ million and $\$ 28$ million respectively. These nanocaps constitute the bulk (95.38\%) of Canadian IPOs.

We estimate the median market-to-book ratio in each group. This ratio gives us an estimate of the expected growth rate and is a classic relative valuation indicator. In GROUP1, GROUP2 and GROUP3, the median market-to-book ratio is 3.17, 3.65 and 2.17 respectively. Growth expectations for seed and early-stage IPO firms are higher than those reported on the AIM (2.74), and far surpass the 1.82 reported for the London Stock Exchange and the NASDAQ by Gerakos et al. (2013). Canadian investors seem to place high value on seed and early-stage IPOs. 
To put the IPOs of GROUP1 and GROUP2 in perspective, note that the average deal size reported by the Canadian VC industry increased from $\$ 1.7$ million in 1996 to $\$ 3$ million in 2002 (Industry Canada 2002), and reached $\$ 6.1$ million in 2016. In Canada, the GP of most IPOs have been lower than the average deal size in the VC industry until 2014, when large IPOs predominated. This is a paradoxical situation because such low GP imply tiny capitalization and float. The liquidity of such stocks is likely to remain very low, which suggests high volatility, large spreads and high transaction costs. As Bekaert and Harvey (1998) argue in the stock market context, liquidity is of paramount importance in part because it is necessary for the effective generation and dissemination of firm-specific information. They maintain that illiquidity and associated increased transaction costs are the most important symptoms of inefficient stock markets. Such problems offset the benefits of a stock market for the economy. Similarly, Nassr and Wehinger (2015 p.51) find that "liquidity is most likely the key challenge in publicly traded SME equity, with SME shares tending to be very illiquid, hampering the ability of early-stage investors to realise their investment through normal exit." Even in GROUP4, most firms are small, with a limited float, unsuited to investment requirements of financial institutions and unlikely to attract financial analysts' coverage. They suffer from an "illiquidity tax" that deters investment by institutional investors that require a liquid trading market (Rose and Davidoff 2016).

With median revenues of $\$ 173.43$ million and a market capitalization of $\$ 195.48$ million, the issuers in GROUP4 are in the same range as the smallest US IPOs (Lowry et al. 2017), and fulfill the NASDAQ listing requirements. They constitute only $4.62 \%$ of the sample.

VCs are involved in $8.48 \%$ of IPO firms in our sample, with some variations across the groups: from $2.64 \%$ in firms at the seed stage to $15.84 \%$ in GROUP2 (firms that report revenues and losses). In each group, firm size and total assets decrease when we delete VC-backed IPOs. This indicates that $\mathrm{VC}$ is associated with the largest issuers in each group. We observe a huge difference between the median GP in both groups. VC-backed IPOs raise \$25 million, while non-VC-backed IPOs raise $\$ 1$ million. This is true for each size group except for GROUP4. This confirms the significant role of VC certification during the IPO process.

Insert Table 4 here 


\subsection{Average abnormal returns}

In panel A of Table 5, we report the average abnormal returns for the whole sample, using two weighting schemes, two initial prices and two different benchmarks. The long-run abnormal returns following IPOs are, on average, negative and significantly different from zero when the benchmark is the $\mathrm{S} \& \mathrm{P} / \mathrm{TSX}$. The average of the BHAR distribution ranges from $-9.90 \%$ to $-42.26 \%$.

The choice of the initial price has a strong influence on abnormal returns. The market price is on average higher than the issue price set by investment bankers. This observation is consistent with the observation of a positive initial return, affirmed in numerous studies across the world (Lowry et al. 2017). Investors that can buy the stocks at the issue price benefit from an abnormal return that is less negative, by approximately 800 to 1,100 basis points, than that of investors that buy the stock after the IPO on the secondary market. In both cases, for the whole sample, the average abnormal returns are negative and differ statistically from zero.

The choice of the benchmark matters. The average abnormal returns are less negative with the BMO Small Cap than with the S\&P/TSX because smaller firms posted, on average, poor returns during the study period. From the beginning of 1997 to the end of 2014, we estimate a yearly annual rate of return of $7.2 \%$ for the S\&P/TSX, $2.7 \%$ for the BMO Small Cap and $0.2 \%$ for the TSXV index. This explains the difference of about $15 \%$ on the three-year BHAR depending on the choice of benchmark. From the viewpoint of typical individual investors, the reference index is likely to be the S\&P/TSX. This is why we focus on this benchmark.

For all estimation models, the statistical tests generally confirm our first proposition.

Insert Table 5 here

\subsection{Abnormal returns and development stage}

Panels B to E of Table 5 present the results relative to the second proposition, which posits that the average abnormal return of Canadian IPOs is lower for firms at an early development stage than for more mature firms. Value-weighted (VW) abnormal returns override equally weighted (EW) abnormal returns. The differences between the results induced by the weighting scheme come from the huge weight of a small number of very large IPOs in several groups. In GROUP1, where the median GP are less than $\$ 1$ million, two firms issue more than $\$ 300$ million and constitute 11.31\% of the market value of this group of 1100 issuers. They post positive abnormal returns, and VW 
average abnormal returns are generally higher than EW abnormal returns. For this reason, we focus our analysis on EW returns and we report $\mathrm{VW}$ abnormal returns to allow a comparison with previous studies.

For all groups except GROUP4, comprising the largest and most profitable firms, the average abnormal returns based on the S\&P/TSX index are negative and generally statistically different from 0. Our results are consistent with proposition 2. Using market price and the S\&P/TSX, we observe an average abnormal return that increases from $-46.66 \%$ in GROUP1 firms to $-0.41 \%$ (not significant) for GROUP4 firms. In this group, average abnormal returns are positive and statistically significant even when estimated from the issue price and relative to the BMO Small Caps index.

The relationship between the average EW returns and the development stage is monotonic, and holds whatever the initial price used to estimate returns. Using the issue price and the S\&P/TSX index, the EW return of large firms reporting profits reaches $7.76 \%$, but is not significantly different from 0 , due to the very large dispersion in the return distribution. When the benchmark is the BMO Small Cap, we observe the same monotonic relationship between the development stage and the average abnormal EW returns. Average abnormal returns remain predominantly negative, except in GROUP4, but they are less negative than those estimated with the S\&P/TSX.

The returns observed in the group of the largest and most profitable IPOs do not differ significantly from 0 . This indicates that two very different realities coexist in the Canadian market. Most IPOs are small, reporting losses or even at a pre-revenue stage. They post negative abnormal returns during the three years following their listing. However, investors benefit from a fair return when they invest in large and profitable firms. The problem is that such IPOs constitute only $4.62 \%$ of the whole sample, and $15.58 \%$ of TSX IPOs. Figure 3 illustrates the large difference between the abnormal returns of the small group of GROUP4 issuers and the other issuers.

Insert Figure 3 here

To determine the extent that the two stock markets differ, we report the analysis of long-run returns by exchange in panels $\mathrm{F}$ and $\mathrm{G}$ of Table 5 . When the benchmark is the S\&P/TSX, TSX IPOs post a significant negative average return of $-29.69 \%(-22.50 \%)$ using the market (issue) price. Accordingly, investors in TSX IPOs sustained negative abnormal returns during the studied years 
with the S\&P/TSX index as a benchmark. The average abnormal returns are generally not significant when we use the Small Cap Index.

The average abnormal return of TSXV IPOs is strongly negative and statistically significant for all combinations of benchmark and initial price. It reaches $-47.11 \%$ for $\mathrm{EW}$ abnormal returns from the market price. This result is consistent with the poor returns generally observed on the junior market, and can explain why the decrease in the number of IPOs has been stronger on the TSXV than on the TSX. These results are consistent with our second proposition.

\subsection{Evolution}

We report above the sustained increase in the median issue size over three decades, which differs depending on the exchange. Larger issues are less prone to asymmetric information, and less compatible with the lemon market proposition than nano-cap stocks are. In Table 6, we report the analysis of abnormal returns by sub-period and exchange. On the TSX, we observe an improvement in post-listing performance. Since 2006, VW returns have been positive and significant if we use BMO Small caps as the benchmark, and do not differ from 0 using the S\&P/TSX index. EW abnormal returns remain negative and significant when the S\&P/TSX is the benchmark. The strong difference between EW and VW is the result of a few very large IPOs. The improvement in performance is consistent with the proposition that the poor post-listing returns are associated with the small IPOs of unprofitable firms. On the TSXV, where issue size is very low and where the proportion of loss firms has been approximately $95 \%$ since 2006, we observe a decrease in the average abnormal performance. Since 2006, the TSXV and the TSX exhibit contrasting post-listing performance. The differences between the industry weights in each exchange partly explain this gap. We estimate the abnormal returns by industry and period. ${ }^{17}$ From 2006 to 2012, the EW abnormal return estimated with the S\&P/TSX index from the market price is $-53.23 \%$ for NR IPOs, and $-22.31 \%$ for the other non-NR IPOs.

\section{Insert Table 6 here}

\subsection{Abnormal return distribution and skewness}

\footnotetext{
${ }^{17}$ We do not report the detailed results, for the sake of brevity. We present a multivariate analysis of the abnormal returns in the next section.
} 
Table 7 presents the distributions of abnormal returns by group, using the BMO Small Cap (Panel A) and the S\&P/TSX as a benchmark (Panel B). We use the market price to estimate the BHAR and test the normality of distributions using the Shapiro-Wilk test. We illustrate the distribution of abnormal returns in Figure 4.

The distributions of abnormal returns are highly consistent with the lottery stock story. Overall, using the S\&P/TSX as a benchmark, about $78.55 \%$ of IPOs provided negative returns (Panel B). This proportion reaches $81.09 \%$ in the group of small IPOs without revenues. The proportion of negative returns decreases as the development stage of the firms improves. However, even for the largest firms, the proportion of negative returns is higher than $60 \%$. In this group, $16.16 \%$ of IPOs delivered a three-year abnormal return higher than 100\%, which can be considered as a fair VC rate of return. ${ }^{18}$ With a probability of negative returns in the vicinity of $80 \%$, a probability of a high rate of return of about $10 \%$ and negative expected returns, the small Canadian IPOs in groups 1 to 3 fit the description of lottery stocks particularly well.

For each group, the skewness coefficient indicates a strong departure from normality, ranging from 1.65 in GROUP1 to 0.97 in GROUP4. In the case of subsequent equity offerings, Hsu et al. (2016) consider stocks whose average skewness is 1.44 to be lottery stocks. The statistical tests point to a significant level of departure from normality, for each group. These observations are consistent with proposition 3 .

\section{Insert Table 7 and Figure 4 here}

\subsection{Multivariate analysis}

Several interrelated factors are likely to explain the differences in IPOs' post-listing returns, and we provide only univariate analysis in the previous tables. To supplement this analysis, we report the results of the multivariate analysis using the model described in equation (5) in Table 7. We use robust regression because OLS residuals depart from the normality assumption. The coefficient of the dummy variable associated with GROUP4 is positive and highly significant. The coefficient is 0.29 when the $\mathrm{S} \& \mathrm{P} / \mathrm{TSX}$ is the benchmark. Accordingly, the abnormal return for this group is higher than that of GROUP3, and the gap between both groups is about $29 \%$ when the other

18 A minimum respectable annual return on a VC Fund is generally estimated at $20 \%$ to $25 \%$ : http://www.angelblog.net/Venture_Capital_Funds_How the_Math_Works.html. 
variables are considered. In Table 5, we report a difference of about 35\%, in the same range. The coefficient of the dummy variable associated with GROUP2 is negative and significant, and the coefficient is about $-10 \%$, consistent with Table 5 . We do not observe any significant differences between GROUP1 and reference GROUP3. IPOs launched during cold issue periods perform better than those launched during other market conditions, a result in line with previous studies.

Insert Table 8 here

\section{DISCUSSION AND CONCLUSION}

In this paper, we shed light on the specificities of the Canadian IPO market, which is unique in the world. The main specificity of this market is the early development stage of most firms, which list at a pre-revenue stage, and the tiny proportion of issuers that meets international standards. Generally, investing in firms at an early development stage is limited to specialized investors. We also qualify the asserted decrease in IPOs that differs depending on the exchange and industry. On the TSX, we observe a strong increase in issue size since 1986. The activity observed since 2006 is, on average, greater than that reported before the hot issue market of the end of the $1980 \mathrm{~s}$. The decrease in IPOs is probably attributable to more than one cause. In this section, we briefly discuss the explanations proposed in Canada. We then examine the extent that the arguments raised in the US can be used in Canada. Third, we suggest that our empirical results can be a complementary explanation and conclude the paper.

\subsection{Previous explanations in Canada}

The reasons stated in the few Canadian reports and papers devoted to the decrease in IPOs comprise the corporate governance dimension, including managers' increasing exposure to pressure from shareholders, and the poor perception of the public market by private company owners (PWC \& FMC 2011, Tingle et al. 2014). We cannot rule out the possibility that some characteristics of the Canadian governance system, like the frequent use of dual class stock, partially explains the poor performance of IPOs. Dual class stock has been used by Canadian corporations for the past sixty years (Ben-Ishai and Puri 2006), yet institutional investors are increasingly voicing opposition to IPOs' promoting outsized executive and founder control. The advantage of dual-class stock at IPO time seems to be decreasing markedly (Bebchuk and Kastiel 2017). Small issue size prevents institutional investors from participating in the market (PWC \& FMC 2011). Lack of liquidity is also cited as a problem that hinders operations on the secondary market (PWC \& FMC 2011), but 
limited liquidity is inherent in the listing of tiny firms. The general picture is that managers of private firms have a negative perception of the IPO market in Canada.

The increasing availability of alternative sources of funds, which include business angels, VCs and private equity, ${ }^{19}$ can explain why private firms choose to escape the burden of costs and constraints of public funding (Magnan and Campbell 2014). Strong acquisition activity by large and often foreign firms ${ }^{20}$ has provided an increasing opportunity for good quality firms to finance their growth without using the IPO market (Carpentier and Suret 2014, Carpentier and Suret 2015b).

\subsection{What explanations in the US can work in Canada?}

In the US, the most common explanations for the decline in IPOs are the increasing cost of complying with Sarbanes-Oxley area regulation, mainly section 404, and the litigation climate surrounding IPOs. However, Canada did not import most of this regulation, avoided the most expensive requirements such as the auditing of financial controls, and is free from the litigation problems (Tingle et al. 2014). This avenue is thus probably not a good explanation for the Canadian results.

Weild and Kim (2009) argue that changes in the IPO market structure is the main explanation. This includes the decline in the ecosystem of underwriters. A strong concentration movement occurred in the Canadian brokerage industry from 1986 to 2011 . The acquisition of 52 small brokerage firms by large firms can be associated with 56.5\% of the decrease in IPOs, because the acquirers of these small firms did not continue to participate in small IPOs. However, the small brokerage firms that remain independent or merge also significantly decreased their activity in the field. Accordingly,

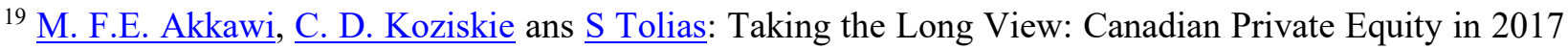
Torys Quarterly: in: With the New January 16, 2017, https://www.torys.com/insights/publications/2017/01/taking-the-long-view-canadian-private-equity-in-

2017; for Business Angels: 2016 Report on Angel Investing Activity in Canada https://www.nacocanada.com/cpages/research and for VC: VC \& PE Canadian Market Overview 2016 https://www.cvca.ca/wp-content/uploads/2017/02/CVCA-2016-Canadian-Overview-Eng_Final.pdf. "At $\$ 3.2 \mathrm{~B}, 2016 \mathrm{VC}$ investment exceeded 2015 by 41 per cent $(\$ 2.3 \mathrm{~B})$ and is the highest on record since 2001"

20 J. Berkow U.S. giants gobbling up Canadian technology startups, Financial Post, March 15, 2012 http://business.financialpost.com/entrepreneur/fp-startups/u-s-giants-gobbling-up-canadian-technologystartups. D. Davila, Too many Canadian startups are bought out. Here's how to change that, The Globe and Mail, March 25, 2017, https://beta.theglobeandmail.com/report-on-business/rob-commentary/too-many-canadian-startups-arebought-out-heres-how-to-change-that/article28024596/?ref=http://www.theglobeandmail.com\&
} 
the concentration in the brokerage industry cannot be the main reason for the decrease in IPO activity.

The economies of scope hypothesis (Ritter et al., 2013) is grounded in the observation that structural changes in recent years favour big firms at the expense of small firms. Ritter contends that getting big fast is increasingly important, mainly in the technology industry, as a consequence of globalization and improvements in communication technology. The strategy whereby a small

independent company grows by using its own resources and ultimately makes an IPO is becoming less advantageous than the acquisition by a large company that can exploit innovation fully and rapidly (Gao et al. 2013, Ritter et al. 2013, Carpentier and Suret 2014, Carpentier and Suret 2015b). Accordingly, the propensity of VCs and business angels to exit their investment by trade sales has increased. Since 2000, based on CVCA reports, Canadian VCs have exited 94 times using an IPO and 521 times through a trade sale or a merger (Table 3). Because many angels now act in groups, they are able to finance the firms until they can be acquired, and they do not see the IPO as an alternative to exit, as Carpentier and Suret (2015b) showed. A second implication of the economies of scope hypothesis is that small firms have become less profitable; indeed, the proportion of IPO firms reporting losses has increased sharply. If the most promising firms no longer consider going public, and if the profitability of the remaining IPO firms declines, then the most likely outcome of IPOs is very poor market performance.

\subsection{Contribution to the debate, and conclusion}

The average return estimated during the three years following Canadian IPOs is abnormally low, statistically significant and in the vicinity of $-20 \%$ to $-40 \%$ for all IPOs except for a small subsample of profitable and large issuers with more than $\$ 25$ million in net assets. For this group, we note non-significant abnormal returns. Accordingly, the losses incurred by the investors involved in IPOs are economically large. Moreover, a large proportion of IPOs post negative abnormal performance. This result seems consistent with the lemon market proposition. Investors' perception of the IPO performance on the Canadian market is therefore likely to be very negative.

When IPOs are grouped based on development indicators, from those reporting no revenues to the largest and most profitable firms, we observed a monotonic relationship between the average abnormal returns and the development level. Among small firms, those reporting no revenues at the IPO exhibited the poorest performance. In most markets, such firms are simply banned from 
listing, as Schwartz (2017) advances. The small subsample of IPOs that approximately fit the NASDAQ minimum listing requirements has provided a fair return. However, this group is so small that it cannot drive the average return toward positive values, even for the sub-sample of TSX IPOs. Negative abnormal performance occurs on both the main and the junior markets.

Following Leleux and Muzyka (1997) in Europe, we put forth the disappointment hypothesis as an additional explanation. The very poor performance provided by small IPOs in recent decades can explain the lack of demand for this type of issue, which we observe since early 2001 . The most interesting question is why investors have participated in this market that provides very poor average returns, for so many years. The large skewness of the return distribution is consistent with the lottery stock story. Because such stocks provide large returns in so few cases, investors buy them as lottery tickets. Globally, our results confirm the irrational investor behaviour that has prevailed for decades, causing investors to lose huge sums of money. However, we suggest that the recurrent losses have led investors to form more rational expectations regarding small IPOs' prospects, and to become more selective. This is consistent with the observation that the TSX IPO market is becoming increasingly dominated by large firms.

To revitalize the Canadian IPO market, several recommendations have been made along three main dimensions. First, the regulatory burden for the smaller issuers could be studied and reduced (Magnan and Campbell 2014). Second, individual investors' participation in small IPOs could be stimulated, notably using tax incentives. This includes implementing "exit" tax incentives, which differ from tax credits offered when investors buy the stocks (PWC \& FMC 2011, Working Group 2016). Third, two reports suggest that the supply of IPOs should be increased by promoting the public financing of small firms (PWC \& FMC 2011, Working Group 2016). This is a challenge because of the negative perception of stock exchanges by the entrepreneurs (Magnan and Campbell 2014) and because "the public markets and the legal and regulatory apparatus surrounding them have evolved in a way that provides strong disincentives to managers to take their businesses public" (Tingle et al. 2014).

Our results illustrate the limits of the previous suggestions. If smaller issuers systematically provide investors with very poor returns and generate a lemon market situation, it would be better to increase the listing requirements than to reduce the regulatory burden. We argue that more stringent minimum listing requirements could eliminate pre-revenue firms and improve the post-listing 
performance and the market perception, in line with Schwartz (2017). Alternatively, the small IPO market could be restricted to qualified investors. Tax incentives are unlikely to stimulate the market in the long run. They can have negative effects (Carpentier and Suret 2006, Magnan and Campbell 2014). Mainly, allowing a tax credit when buying a stock in a context of low supply is likely to increase the stock price and to reduce the post-listing returns. Such incentives also contribute to redirecting available financing to poorly performing entities, which contrasts with good public policy. Stimulating the supply of new firms will probably be difficult unless the Canadian IPO market loses its lemon market characteristics. Our analysis brings forth two positive points. First, the characteristics of IPOs on the main market have become more similar to those of classic IPOs on major exchanges. Second, there is now a clear distinction between the TSX and the TSXV IPO markets. We contend that this notable segmentation is a step in the right direction. 


\section{References}

Akerlof, G. A. (1970). The Market for "Lemons:" Quality Uncertainty and the Market and Mechanism. The Quarterly Journal of Economics 84: 488-500.

Amit, R., J. Brander and C. Zott (1998). Why do Venture Capital Firms Exist? Theory and Canadian Evidence. Journal of Business Venturing 13(6): 441-466.

Ang, J. and S. Zhang (2015). Evaluating Long-Horizon Event Study Methodology. Handbook of Financial Econometric and Statistics. C-F. Lee J.C. Lee. New York, Springer: 383-411.

Barberis, N. and M. Huang (2009). Stocks as Lotteries: The Implications of Probability Weighting for Security Prices. American Economic Review 98(5): 2066-2100.

Bebchuk, L. A. and K. Kastiel (2017). The Untenable Case for Perpetual Dual-Class Stock Virginia Law Review 103: 585-631.

Bekaert, G. and C. R. Harvey (1998). Capital markets: An engine for economic growth. The Brown Journal of World Affairs 5(1): 33-53.

Ben-Ishai, S. and P. Puri (2006). Dual Class Shares in Canada: A Historical Analysis Dalhousie Law Journal 29(1): 117-157.

Black, B. S. (2001). The Legal and Institutional Preconditions for Strong Securities Markets. UCLA Law Review 48: 781-858.

Boardman, A. E., C. Laurin and A. R. Vining (2002). Privatization in Canada: Operating and Stock Price Performance with International Comparisons. Canadian Journal of Administrative Sciences 19(2): 137-154.

Bradley, D. J., J. W. Cooney, S. D. Dolvin and B. D. Jordan (2006). Penny Stock IPOs. Financial Management 35(1): 5-29.

Brav, A., C. Geczy and P. A. Gompers (2000). Is the Abnormal Return Following Equity Issuance Anomalous? Journal of Financial Economics 56: 209-249.

Carpentier, C., J.-F. L'Her and J.-M. Suret (2010). Stock Exchange Markets for New Ventures. Journal of Business Venturing 25 (4): 403-422.

Carpentier, C., F. Romon and J.-M. Suret (2017). Are Investors Rational When Valuing Loss Firms? Journal of Behavioral Finance Forthcoming.

Carpentier, C. and J.-M. Suret (2006). The Quebec Stock Saving Plan : A Tax Expenditure Analysis. Canadian Tax Journal 54(1): 142-166.

Carpentier, C. and J.-M. Suret (2014). Post-Investment Migration of Quebec Venture-capitalbacked new Technology-based Firms. Canadian Journal of Regional Science 37(13): 71-80.

Carpentier, C. and J.-M. Suret (2015a). Angel Group Members' Decision Process and Rejection Criteria: A Longitudinal Analysis. Journal of Business Venturing 30(6): 808-821.

Carpentier, C. and J.-M. Suret (2015b). Canadian Business Angel Perspectives on Exit: A Research Note. International Small Business Journal 33(5): 582-593. 
Chemmanur, T. J. and P. Fulghieri (2014). Entrepreneurial finance and innovation: An introduction and agenda for future research. Review of Financial Studies 27(1): 1-19.

Choi, S. J. (2006). Behavioral Economics and the Regulation of Public Offerings. Lewis \& Clark Law Review 10(1): 85-135.

Choi, S. S. and A. C. Pritchard (2003). Behavioral Economics and the SEC. Stanford Law Review 56(1): 1-74.

Davidsson, P. and B. Honig (2003). The Role of Social and Human Capital Among Nascent Entrepreneurs. Journal of Business Venturing 18(3): 301-331.

Dutta, S., K. MacAulay, T. Hynes and M. Oxner (2008). Curbing their Enthusiasm: A Canadian Look at the Value of Analysts' Recommendations (1996 to 2004). Canadian Investment Review Spring: 8-19.

Eberhart, R. and C. E. Eesley (2017). Intermediaries and Entrepreneurship. Working Paper, October 7.

Eckbo, B. E. and O. Norli (2005). Liquidity Risk, Leverage and Long-run IPO returns. Journal of Corporate Finance 11(1/2): 1-35.

Espenlaub, S., A. Khurshed and A. Mohamed (2012). IPO Survival in a Reputational Market. Journal of Business Finance \& Accounting 39(3-4): 427-463.

Fenn, G. W., N. Liang and S. Prowse (1997). The Private Equity Market: An Overview. Financial Markets, Institutions \& Instruments 6(4): 1-106.

Field, L. C. and M. Lowry (2009). Institutional versus Individual Investment in IPOs: The importance of Firm Fundamentals. Journal of Financial and Quantitative Analysis 44(3): 489-516.

Gao, X., J. R. Ritter and Z. Zhu (2013). Where Have All the IPOs Gone? Journal of Financial and Quantitative Analysis 48(6): 1663-1692.

Gerakos, J., M. Lang and M. Maffett (2013). Post-Listing Performance and Private Sector Regulation: The Experience of London's Alternative Investment Market. Journal of Accounting and Economics 56(2-3, Supplement 1): 189-215.

Giudici, G. and P. Roosenboom (2004a). The Long Term Performance of IPO on Europe's New Markets. The Rise and Fall of Europe's New Stock Markets. G. Giudici and P. Roosenboom. Amsterdam, Elsevier JAI: 329-354.

Giudici, G. and P. Roosenboom (2004b). The Rise and Fall of Europe's New Stock Markets: Preface. The Rise and Fall of Europe's New Stock Markets. G. Giudici and P. Roosenboom. Amsterdam, Elsevier JAI. Volume 10: ix xiv.

Goergen, M., A. Khurshed, J. A. McCahery and L. Renneboog (2003). The Rise and Fall of the European New Markets. Venture Capital Contracting and the Valuation of High-technology Firms. J.A. McCahery and L. Renneboog (eds.). Oxford, Oxford University Press: 464-492.

Harwood, A. and T. Konidaris (2015). SME Exchanges in Emerging Market Economies : a Stocktaking of Development Practices World Bank Policy Research Working Paper 7160 
Helwege, J. and N. Liang (2004). Initial Public Offerings in Hot and Cold Markets. Journal of Financial and Quantitative Analysis 39(3): 541-569.

Hsu, J., T.-H. Yang and P.-S. Sung (2016). SEO Firms' lottery-like Characteristics, Institutional Ownership, and Long-run Performance. Journal of Business Research 69(6): 2160-2166.

Industry Canada (2002). Canadian Venture Capital Activity: An Analysis of Trends and Gaps 1996-2002. Report: 292 p.

Jain, B. A., N. Jayaraman and O. Kini (2008). The Path-to-profitability of Internet IPO firms. Journal of Business Venturing 2(2): 165-194.

Jenkinson, T. and A. Ljungqvist (2001). Going Public: The Theory and Evidence on How Companies Raise Equity Finance, Second edition. Oxford : Oxford University Press.

Jog, V. M. (1997). The Climate for Canadian Initial Public Offerings. Financing Growth in Canada. P. Halpern ed., University of Calgary Press: 357-401.

Kahneman, D. and A. Tversky (1979). Prospect Theory: An Analysis of Decision under Risk. Econometrica 47(2): 263-291.

Kooli, M. and J.-M. Suret (2004). The Aftermarket Performance of Initial Public Offerings in Canada. Journal of Multinational Financial Management 14(1): 47-66.

Kumar, A. (2009a). Hard-to-value Stocks, Behavioral Biases, and Informed Trading. Journal of Financial and Quantitative Analysis 44(06): 1375-1401.

Kumar, A. (2009b). Who Gambles in the Stock Market. The Journal of Finance 64(4): 1889-1933,. La Porta, R., F. Lopez-De-Silanes and A. Shleifer (2006). What Works in Securities Laws? The Journal of Finance 61(1): 1-32.

Langevoort, D. C. (2002). Taming the Animal Spirits of the Stock Markets: A Behavioral Approach to Securities Regulation. Nortwestern University Law Review. 97(1): 135-153.

Leleux, B. F. and D. F. Muzyka (1997). European IPO Markets: The Post-issue Performance Imperative. Entrepreneurship: Theory \& Practice 21(4): 111.

Lepone, G. and D. Wright (2014). Investor Behaviour and Lottery Stocks World finance conference (2 - 4 July 2014 : Venice).

Locke, S. M. and K. Gupta (2008). The Performance of Entrepreneurial Companies Post-listing on the New Zealand Stock Exchange. Venture Capital: An International Journal of Entrepreneurial Finance 10(1): 87-110.

Lowry, M., R. Michaely and E. Volkova (2017). Initial Public Offering: A Synthesis of the Literature and Directions for Future Research. Foundations and Trends in Finance Forthcoming

Magnan, M. and B. Campbell (2014). Le premier appel public à l'épargne et les sociétés québécoises : état de la situation. Rapport de projet CIRANO 2014RP-09.

Mahoney, P. G. (1995). Mandatory Disclosure as a Solution to Agency Problems. The University of Chicago Law Review 62(3): 1047-1112. 
Nassr, I. K. and G. Wehinger (2015). Opportunities and Limitations of Public Equity Markets for SMEs. OECD Journal: Financial Market Trends 3(1): 1-36.

Pandes, J. A. and M. J. Robinson (2013). The Canadian Junior IPO Market and the Capital Pool Company Program. Handbook of research on IPOs. M. Levis \& S. Vismara (Eds.). London, Edward Elgar: 124-140.

PWC \& FMC (2011). Toward More Democratic Corporate Financing, . Report, Fraser Milner Casgrain LLP and PricewaterhouseCoopers, .

Ritter, J. (2016). Initial Public Offerings: Updated Statistics University of Florida.

Ritter, J. R. (2017). Initial Public Offerings: Tables Updated Through 2016. Available on line at: https://site.warrington.ufl.edu/ritter/files/2017/04/IPOs2016VC-backed.pdf.

Ritter, J. R., A. Signori and S. Vismara (2013). Economies of Scope and IPO Activity in Europe. Handbook of Research on IPOs. M. Levis and S. Vismara (Eds). Cheltenham, Edward Elgar Publishing, .

Rose, P. and S. Davidoff (2016). Have All the IPOs Gone? The Hard Life of the Small IPO. Harvard Business Law Review 6(1): 83-128.

Schwartz, J. (2017). Venture Exchange Regulation: Listing Standards, Market Microstructure, and Investor Protection. The Handbook on Law and Entrepreneurship Gordon Smith \& Christine Hurt eds., Cambridge University Press: Forthcoming.

Smithson, N. and C. Firer (2007). Performance of Newly Listed Mining Stocks on the London AIM and Toronto TSX-V Stock Exchanges. Investment Analysts Journal 36(66): 31-41.

Suret, J.-M. and É. Cormier (1997). The Quebec Stock Savings Plan : Overview and Assessment. Financing Growth in Canada. P. Halpern Ed., University of Calgary Press: 585-623.

Tingle, B. C., J. A. Pandes and M. J. Robinson (2014). The IPO Market in Canada: What a Comparison with the United States Tells Us About a Global Problem. Canadian Business Law Journal 54(3): 321-367.

Ursel, N. (2000). Priced ToSell The Evolution of Underpricing in Canadian Initial Public Offerings. Canadian Business Economics (February): 15-20.

Vismara, S., S. Paleari and J. R. Ritter (2012). Europe's Second Markets for Small Companies. European Financial Management 18(3): 352-388.

Weild, D. and E. Kim (2009). Market Structure is Causing the IPO crisis. Grant Thornton White Paper.

WFE (2016). Report on SME Exchanges. World Federation of Exchanges.

Working Group (2016). Public Listing: The Weak Link in Quebec's Corporate Finance Ecosystem. Report of the Working Group on the Shortage of Publicly Traded Quebec Companies.

Xiao, Y. and C. Yung (2015). Extrapolation Errors in IPOs. Financial Management 44(4): 713751. 
Table 1 Number and characteristics of initial public offerings (IPOs) by stock exchange between 1986 and 2016. Median (med.) gross proceeds (GP) are in $\$$ million. N means number of IPOs. $\% \mathrm{Neg}(\mathrm{NS})$ means proportion of issuers reporting pre-IPO negative earnings (without revenues).

\begin{tabular}{|c|c|c|c|c|c|c|c|c|c|c|c|c|c|c|c|}
\hline \multirow[t]{2}{*}{ Year } & \multicolumn{5}{|c|}{ Canada } & \multicolumn{5}{|c|}{ TSX } & \multicolumn{5}{|c|}{ TSXV } \\
\hline & $\mathrm{N}$ & $\begin{array}{c}\text { GP } \\
\text { mean }\end{array}$ & $\begin{array}{c}\text { GP } \\
\text { med. }\end{array}$ & $\begin{array}{c}\% \\
\text { Neg }\end{array}$ & $\begin{array}{c}\% \\
\text { NS }\end{array}$ & $\mathrm{N}$ & $\begin{array}{c}\text { GP } \\
\text { mean }\end{array}$ & $\begin{array}{c}\text { GP } \\
\text { med. }\end{array}$ & $\begin{array}{c}\% \\
\text { Neg }\end{array}$ & $\begin{array}{c}\% \\
\text { NS }\end{array}$ & $\mathrm{N}$ & $\begin{array}{c}\text { GP } \\
\text { mean }\end{array}$ & $\begin{array}{c}\text { GP } \\
\text { med. }\end{array}$ & $\begin{array}{c}\% \\
\text { Neg }\end{array}$ & $\begin{array}{c}\% \\
\text { NS }\end{array}$ \\
\hline 1986 & 267 & 7.08 & 2.00 & 48.02 & 33.48 & 69 & 20.48 & 13.00 & 16.42 & 7.46 & 198 & 2.41 & 0.69 & 61.25 & 44.38 \\
\hline 1987 & 365 & 6.37 & 0.48 & 73.99 & 52.70 & 42 & 46.33 & 15.00 & 28.57 & 19.05 & 323 & 1.18 & 0.40 & 81.50 & 58.27 \\
\hline 1988 & 355 & 0.65 & 0.25 & 92.81 & 74.18 & 6 & 4.32 & 2.75 & 83.33 & 0.00 & 349 & 0.59 & 0.25 & 93.00 & 75.67 \\
\hline 1989 & 199 & 2.98 & 0.28 & 91.41 & 76.07 & 10 & 47.94 & 19.50 & 11.11 & 22.22 & 189 & 0.60 & 0.27 & 96.10 & 79.22 \\
\hline 1990 & 69 & 1.58 & 0.33 & 95.08 & 72.13 & 2 & 31.88 & 31.88 & 0.00 & 0.00 & 67 & 0.67 & 0.32 & 98.31 & 74.58 \\
\hline 1991 & 49 & 10.64 & 0.49 & 75.00 & 59.38 & 10 & 48.97 & 22.13 & 42.86 & 14.29 & 39 & 0.82 & 0.36 & 84.00 & 72.00 \\
\hline 1992 & 43 & 15.74 & 1.54 & 76.47 & 50.00 & 13 & 46.71 & 24.17 & 36.36 & 0.00 & 30 & 2.31 & 0.45 & 95.65 & 73.91 \\
\hline 1993 & 141 & 26.24 & 10.46 & 37.69 & 14.62 & 79 & 44.44 & 25.00 & 22.78 & 6.33 & 62 & 3.04 & 1.57 & 60.78 & 27.45 \\
\hline 1994 & 118 & 28.09 & 2.11 & 52.58 & 24.74 & 49 & 65.47 & 17.28 & 32.61 & 8.70 & 69 & 1.54 & 0.83 & 70.59 & 39.22 \\
\hline 1995 & 89 & 7.48 & 1.35 & 68.66 & 35.82 & 24 & 22.92 & 16.36 & 23.81 & 9.52 & 65 & 1.78 & 0.80 & 89.13 & 47.83 \\
\hline 1996 & 143 & 17.39 & 3.00 & 60.34 & 33.62 & 59 & 39.14 & 25.00 & 41.82 & 14.55 & 84 & 2.12 & 1.00 & 77.05 & 50.82 \\
\hline 1997 & 188 & 23.70 & 1.65 & 69.43 & 33.76 & 51 & 81.94 & 27.00 & 40.00 & 14.00 & 137 & 2.01 & 1.15 & 83.18 & 42.99 \\
\hline 1998 & 98 & 19.99 & 1.75 & 65.31 & 35.71 & 30 & 60.81 & 37.00 & 30.00 & 0.00 & 68 & 1.98 & 1.00 & 80.88 & 51.47 \\
\hline 1999 & 68 & 17.43 & 2.04 & 73.85 & 27.69 & 22 & 50.62 & 30.25 & 38.10 & 0.00 & 46 & 1.56 & 0.80 & 90.91 & 40.91 \\
\hline 2000 & 76 & 24.56 & 4.10 & 72.37 & 36.84 & 33 & 53.99 & 40.00 & 60.61 & 21.21 & 43 & 1.97 & 1.20 & 81.40 & 48.84 \\
\hline 2001 & 31 & 6.57 & 1.53 & 70.97 & 41.94 & 6 & 23.61 & 16.57 & 33.33 & 16.67 & 25 & 2.48 & 1.30 & 80.00 & 48.00 \\
\hline 2002 & 31 & 24.87 & 1.50 & 80.65 & 32.26 & 8 & 89.37 & 41.75 & & & 23 & & 00 & 91.30 & 39.13 \\
\hline 2003 & 36 & 15.85 & 1.79 & 85.71 & 62.86 & 7 & 66.61 & 44.27 & 42.86 & 14.29 & 29 & 3.60 & 1.53 & 96.43 & 75.00 \\
\hline 2004 & 57 & 48.53 & 9.50 & 73.68 & 50.88 & 28 & 95.08 & 46.45 & 60.71 & 28.57 & 29 & 3.58 & 2.00 & 86.21 & 72.41 \\
\hline 2005 & 78 & 24.27 & 6.20 & 75.64 & 69.23 & 33 & 52.69 & 35.07 & 51.52 & 39.39 & 45 & 3.42 & 2.00 & 93.33 & 91.11 \\
\hline 2006 & 90 & 25.84 & 4.55 & 86.67 & 64.44 & 34 & 62.33 & 32.18 & 70.59 & 38. & & & 1.90 & 96.43 & 80.36 \\
\hline 2007 & 102 & 24.38 & 4.75 & 87.25 & 69.61 & 36 & 58.10 & 41.57 & 72.22 & 36.11 & 66 & 5.99 & 1.97 & 95.45 & 87.88 \\
\hline 2008 & 58 & 8.37 & 1.47 & 91.38 & 82.76 & 9 & 38.51 & 31.00 & 44.44 & 22.22 & 49 & 2.84 & 1.00 & 100.00 & 93.88 \\
\hline 2009 & 29 & 35.74 & 1.05 & 85.19 & 62.96 & 5 & 193.31 & 100.00 & 80.00 & 20.00 & 24 & 2.91 & 0.95 & 86.36 & 72.73 \\
\hline 2010 & 72 & 70.74 & 2.66 & 94.37 & 76.06 & 23 & 206.28 & 59.99 & 91.30 & 47.83 & 49 & 7.13 & 1.40 & 95.83 & 89.58 \\
\hline 2011 & 65 & 21.42 & 2.47 & 92.06 & 84.13 & 15 & 78.76 & 40.00 & 66.67 & 46.67 & 50 & 4.22 & 1.50 & 100.00 & 95.83 \\
\hline 2012 & 53 & 20.86 & 0.75 & 96.15 & 92.31 & 5 & 208.02 & 140.00 & 100.00 & 60.00 & 48 & 1.37 & 0.75 & 95.74 & 95.74 \\
\hline 2013 & 22 & 59.09 & 4.39 & 72.73 & 54.55 & 9 & 125.82 & 55.20 & 44.44 & 11.11 & 13 & 12.89 & 0.81 & 92.31 & 84.62 \\
\hline 2014 & 13 & 249.36 & 41.08 & 83.33 & 25.00 & 8 & 404.46 & 149.31 & 71.43 & 0.00 & 5 & 1.20 & 0.78 & 100.00 & 60.00 \\
\hline 2015 & 19 & 104.71 & 49.08 & 78.95 & 57.89 & 11 & 180.19 & 140.00 & 63.64 & 27.27 & 8 & 0.93 & 0.43 & 100.00 & 100.00 \\
\hline 2016 & 9 & 59.63 & 0.69 & 77.78 & 55.56 & 4 & 133.50 & 65.00 & 50.00 & 25.00 & 5 & 0.53 & 0.55 & 100.00 & 80.00 \\
\hline $1986-2016$ & 3033 & 17.53 & 1.04 & 74.76 & 52.61 & 740 & 65.68 & 27.55 & 42.98 & 17.80 & 2293 & 2.00 & 0.61 & 86.40 & 65.36 \\
\hline $1986-1995$ & 1695 & 8.28 & 0.50 & 71.83 & 51.66 & 304 & 40.44 & 16.59 & 25.52 & 9.31 & 1391 & 1.25 & 0.37 & 83.79 & 62.60 \\
\hline $1996-2005$ & 806 & 22.53 & 2.50 & 70.43 & 40.46 & 277 & 61.12 & 30.45 & 45.39 & 16.97 & 529 & 2.32 & 1.20 & 84.78 & 53.91 \\
\hline 2006-2016 & 532 & 39.46 & 2.40 & 88.76 & 72.38 & 159 & 121.85 & 50.00 & 70.89 & 34.81 & 373 & 4.34 & 1.20 & 96.46 & 88.56 \\
\hline
\end{tabular}


Table 2 Number and characteristics of initial public offerings (IPOs) by industry between 1986 and 2016. Median (med.) gross proceeds (GP) are in \$ million. N means number of IPOs. $\% \mathrm{Neg}(\% \mathrm{NS})$ means proportion of issuers reporting pre-IPO negative earnings (without revenues).

\begin{tabular}{|c|c|c|c|c|c|c|c|c|c|c|}
\hline \multirow[t]{2}{*}{ Year } & \multicolumn{5}{|c|}{ Natural resources } & \multicolumn{5}{|c|}{ Non-natural resources } \\
\hline & $\mathrm{N}$ & GP mean & GP med. & $\% \mathrm{Neg}$ & $\% \mathrm{NS}$ & $\mathrm{N}$ & GP mean & GP med & $\% \mathrm{Neg}$ & $\% \mathrm{NS}$ \\
\hline 1986 & 84 & 1.18 & 0.30 & 95.24 & 84.13 & 183 & 9.79 & 5.00 & 29.88 & 14.02 \\
\hline 1987 & 167 & 2.05 & 0.28 & 87.97 & 73.68 & 198 & 10.02 & 0.90 & 62.58 & 35.58 \\
\hline 1988 & 214 & 0.42 & 0.23 & 94.30 & 83.94 & 141 & 1.01 & 0.31 & 90.27 & 57.52 \\
\hline 1989 & 101 & 2.05 & 0.25 & 98.88 & 83.15 & 98 & 3.95 & 0.35 & 82.43 & 67.57 \\
\hline 1990 & 32 & 0.37 & 0.27 & 100.00 & 82.76 & 37 & 2.63 & 0.55 & 90.63 & 62.50 \\
\hline 1991 & 23 & 0.87 & 0.30 & 100.00 & 87.50 & 26 & 19.29 & 1.08 & 50.00 & 31.25 \\
\hline 1992 & 13 & 1.23 & 0.34 & 100.00 & 100.00 & 30 & 22.02 & 4.54 & 66.67 & 29.17 \\
\hline 1993 & 58 & 17.40 & 2.81 & 49.06 & 22.64 & 83 & 32.41 & 15.00 & 29.87 & 9.09 \\
\hline 1994 & 45 & 18.98 & 0.75 & 79.41 & 58.82 & 73 & 33.70 & 5.75 & 38.10 & 6.35 \\
\hline 1995 & 38 & 2.70 & 0.93 & 85.19 & 70.37 & 51 & 11.04 & 1.52 & 57.50 & 12.50 \\
\hline 1996 & 53 & 16.62 & 1.13 & 72.09 & 65.12 & 90 & 17.84 & 6.79 & 53.42 & 15.07 \\
\hline 1997 & 80 & 20.91 & 1.05 & 80.88 & 61.76 & 108 & 25.76 & 2.75 & 60.67 & 12.36 \\
\hline 1998 & 32 & 1.58 & 0.63 & 87.50 & 75.00 & 66 & 28.92 & 3.39 & 54.55 & 16.67 \\
\hline 1999 & 18 & 1.03 & 0.71 & 100.00 & 70.59 & 50 & 23.34 & 3.63 & 64.58 & 12.50 \\
\hline 2000 & 25 & 6.09 & 0.90 & 76.00 & 76.00 & 51 & 33.61 & 23.10 & 70.59 & 17.65 \\
\hline 2001 & 16 & 1.62 & 0.69 & 75.00 & 68.75 & 15 & 11.85 & 5.00 & 66.67 & 13.33 \\
\hline 2002 & 19 & 4.94 & 1.50 & 94.74 & 52.63 & 12 & 56.42 & 3.33 & 58.33 & 0.00 \\
\hline 2003 & 26 & 3.99 & 1.59 & 96.00 & 84.00 & 10 & 46.70 & 22.04 & 60.00 & 10.00 \\
\hline 2004 & 35 & 33.43 & 5.00 & 85.71 & 74.29 & 22 & 72.55 & 36.19 & 54.55 & 13.64 \\
\hline 2005 & 57 & 16.40 & 2.88 & 85.96 & 85.96 & 21 & 45.63 & 25.18 & 47.62 & 23.81 \\
\hline 2006 & 67 & 22.17 & 3.00 & 92.54 & 83.58 & 23 & 36.54 & 20.45 & 69.57 & 8.70 \\
\hline 2007 & 75 & 13.50 & 2.50 & 92.00 & 86.67 & 27 & 54.62 & 39.89 & 74.07 & 22.22 \\
\hline 2008 & 53 & 5.02 & 1.40 & 94.34 & 88.68 & 5 & 43.88 & 41.51 & 60.00 & 20.00 \\
\hline 2009 & 19 & 4.85 & 0.90 & 89.47 & 89.47 & 10 & 94.43 & 1.90 & 75.00 & 0.00 \\
\hline 2010 & 63 & 58.52 & 2.10 & 98.41 & 84.13 & 9 & 156.30 & 61.39 & 62.50 & 12.50 \\
\hline 2011 & 55 & 10.53 & 2.00 & 98.18 & 92.73 & 10 & 81.31 & 34.32 & 50.00 & 25.00 \\
\hline 2012 & 51 & 18.92 & 0.75 & 96.00 & 94.00 & 2 & 70.47 & 70.47 & 100.00 & 50.00 \\
\hline 2013 & 10 & 48.11 & 0.77 & 100.00 & 90.00 & 12 & 68.24 & 41.75 & 50.00 & 25.00 \\
\hline 2014 & 8 & 371.15 & 100.16 & 75.00 & 37.50 & 5 & 54.50 & 41.08 & 100.00 & 0.00 \\
\hline 2015 & 8 & 17.59 & 0.43 & 100.00 & 100.00 & 11 & 168.07 & 140.00 & 63.64 & 27.27 \\
\hline 2016 & 4 & 1.37 & 0.56 & 75.00 & 75.00 & 5 & 106.24 & 60.00 & 80.00 & 40.00 \\
\hline 1986-2016 & 1549 & 12.61 & 0.67 & 89.54 & 77.87 & 1484 & 22.67 & 2.50 & 58.71 & 25.19 \\
\hline 1986-1995 & 775 & 3.55 & 0.30 & 89.34 & 75.12 & 920 & 12.26 & 1.21 & 57.05 & 31.85 \\
\hline 1996-2005 & 361 & 14.14 & 1.30 & 83.98 & 71.81 & 445 & 29.33 & 5.75 & 59.21 & 14.50 \\
\hline 2006-2016 & 413 & 28.29 & 1.60 & 94.42 & 87.14 & 119 & 78.24 & 40.00 & 68.14 & 18.58 \\
\hline
\end{tabular}


Figure 1 Distribution of TSX initial public offerings (IPOs), TSXV IPOs and nonnatural resources (non-NR) IPOs by year

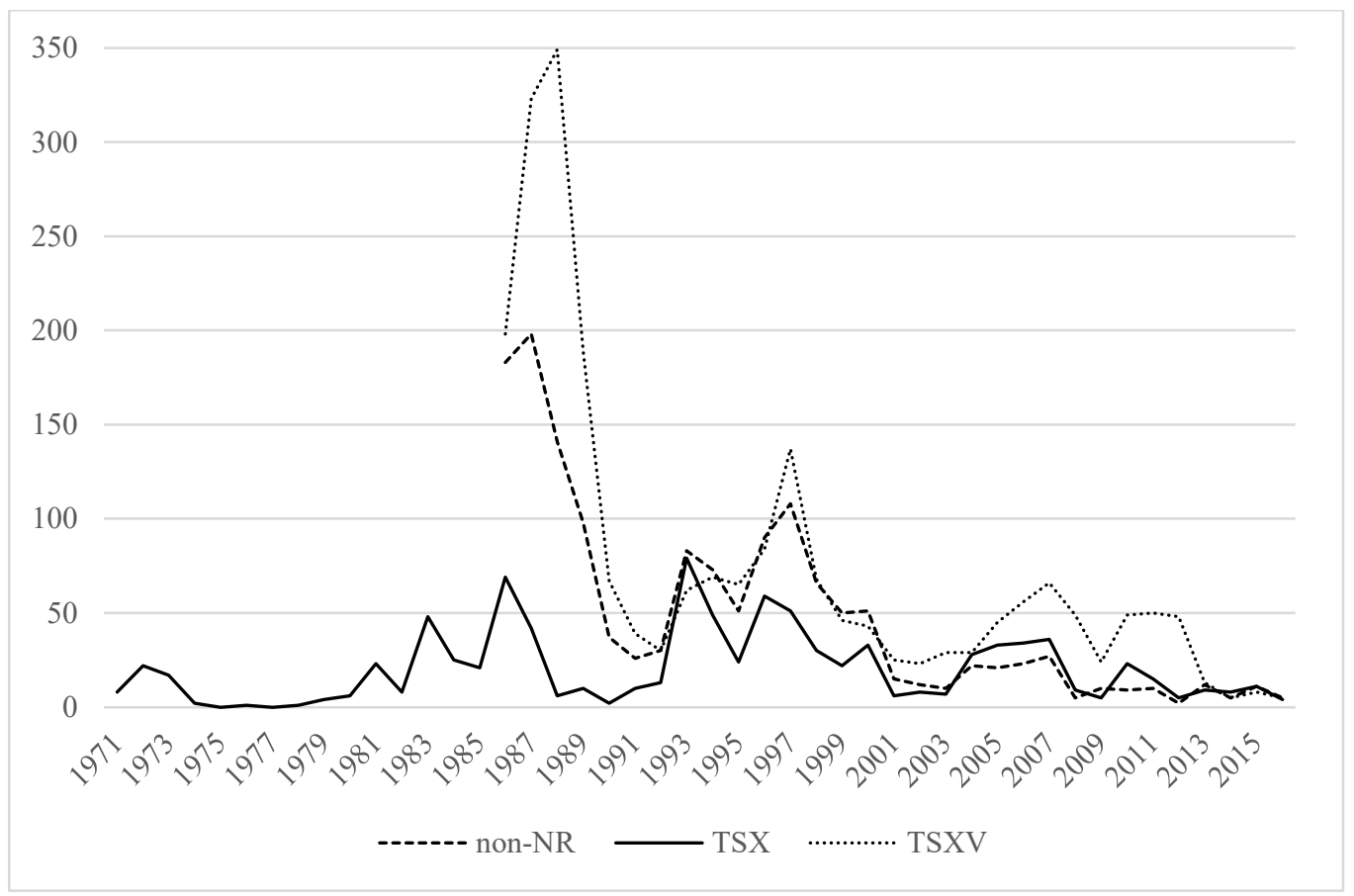

Figure 2 Distribution of natural resource (NR) initial public offerings, Commodity price index and Oil price index by year

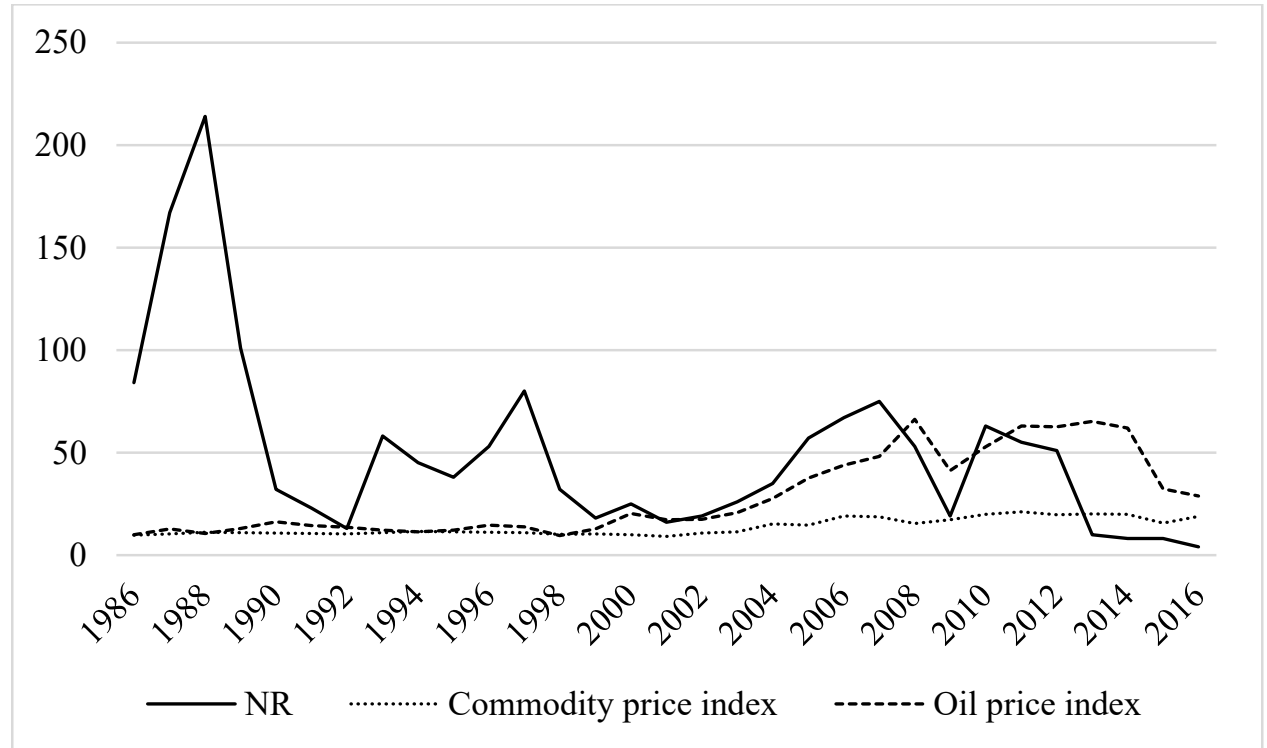


Table 3 Distribution of initial public offerings (IPOs), venture capital-backed (VC-backed) IPOs, in Canada and the US, and mergers and acquisitions (M\&A) in Canada.

\begin{tabular}{|c|c|c|c|c|c|c|c|}
\hline & \multicolumn{3}{|c|}{ US } & \multicolumn{4}{|c|}{ Canada } \\
\hline & IPO & VC-backed IPO & $\%$ & IPOs & VC-backed IPOs & $\%$ & M\&A \\
\hline 1986 & 393 & 79 & 20.10 & 267 & 6 & 2.25 & - \\
\hline 1987 & 285 & 66 & 23.16 & 365 & 4 & 1.10 & - \\
\hline 1988 & 102 & 32 & 31.37 & 355 & 1 & 0.28 & - \\
\hline 1989 & 113 & 40 & 35.40 & 199 & 0 & 0.00 & - \\
\hline 1990 & 110 & 42 & 38.18 & 69 & 0 & 0.00 & - \\
\hline 1991 & 286 & 116 & 40.56 & 49 & 0 & 0.00 & - \\
\hline 1992 & 412 & 138 & 33.50 & 43 & 0 & 0.00 & - \\
\hline 1993 & 509 & 172 & 33.79 & 141 & 15 & 10.64 & - \\
\hline 1994 & 403 & 130 & 32.26 & 118 & 5 & 4.24 & - \\
\hline 1995 & 461 & 186 & 40.35 & 89 & 7 & 7.87 & - \\
\hline 1996 & 677 & 264 & 39.00 & 143 & 8 & 5.59 & - \\
\hline 1997 & 474 & 133 & 28.06 & 188 & 10 & 5.32 & - \\
\hline 1998 & 281 & 77 & 27.40 & 98 & 8 & 8.16 & - \\
\hline 1999 & 477 & 275 & 57.65 & 68 & 18 & 26.47 & 17 \\
\hline 2000 & 381 & 242 & 63.52 & 76 & 23 & 30.26 & 27 \\
\hline 2001 & 79 & 32 & 40.51 & 31 & 8 & 25.81 & 43 \\
\hline 2002 & 66 & 23 & 34.85 & 31 & 3 & 9.68 & 34 \\
\hline 2003 & 63 & 24 & 38.10 & 36 & 1 & 2.78 & 24 \\
\hline 2004 & 173 & 79 & 45.66 & 57 & 13 & 22.81 & 39 \\
\hline 2005 & 159 & 46 & 28.93 & 78 & 9 & 11.54 & 46 \\
\hline 2006 & 157 & 54 & 34.39 & 90 & 7 & 7.78 & 31 \\
\hline 2007 & 159 & 71 & 44.65 & 102 & 12 & 11.76 & 37 \\
\hline 2008 & 21 & 9 & 42.86 & 58 & 1 & 1.72 & 23 \\
\hline 2009 & 41 & 12 & 29.27 & 29 & 1 & 3.45 & 24 \\
\hline 2010 & 91 & 40 & 43.96 & 72 & 1 & 1.39 & 30 \\
\hline 2011 & 81 & 44 & 54.32 & 65 & 2 & 3.08 & 25 \\
\hline 2012 & 93 & 48 & 51.61 & 53 & 1 & 1.89 & 29 \\
\hline 2013 & 157 & 76 & 48.41 & 22 & 4 & 18.18 & 22 \\
\hline 2014 & 206 & 129 & 62.62 & 13 & 4 & 30.77 & 25 \\
\hline 2015 & 115 & 71 & 61.74 & 19 & 4 & 21.05 & 33 \\
\hline 2016 & 74 & 45 & 60.81 & 9 & 0 & 0.00 & 29 \\
\hline 1986-1995 & 3074 & 1001 & 32.56 & 1695 & 38 & 2.24 & - \\
\hline $1996-2005$ & 2830 & 1195 & 42.23 & 806 & 101 & 12.53 & 230 \\
\hline $2006-2016$ & 1195 & 599 & 50.13 & 532 & 37 & 6.95 & 308 \\
\hline $1986-2016$ & 7099 & 2795 & 39.37 & 3033 & 176 & 5.80 & 538 \\
\hline
\end{tabular}

Sources: Ritter (2017), CVCA and Thomson Financial 
Table 4 Sample characteristics of initial public offering (IPO) firms by group.

\begin{tabular}{|c|c|c|c|c|c|c|}
\hline & Total & GROUP1 & GROUP2 & GROUP1-2 & GROUP3 & GROUP4 \\
\hline & & $\begin{array}{c}\text { Issuers } \\
\text { reporting } \\
\text { no } \\
\text { revenues }\end{array}$ & $\begin{array}{c}\text { Issuers } \\
\text { reporting } \\
\text { revenues } \\
\text { and negative } \\
\text { earnings }\end{array}$ & $\begin{array}{c}\text { Issuers } \\
\text { reporting } \\
\text { negative } \\
\text { earnings }\end{array}$ & $\begin{array}{c}\text { Small } \\
\text { profitable } \\
\text { issuers }\end{array}$ & $\begin{array}{c}\text { Large } \\
\text { profitable } \\
\text { issuers }\end{array}$ \\
\hline \multicolumn{7}{|c|}{ Panel A Total Sample } \\
\hline Number & 2145 & 1100 & 505 & 1605 & 441 & 99 \\
\hline Gross proceeds & 1.38 & 0.54 & 1.71 & 0.75 & 9.00 & 67.05 \\
\hline Net earnings & -0.06 & -0.08 & -0.41 & -0.12 & 0.79 & 8.47 \\
\hline Market cap. & 7.94 & 3.31 & 14.10 & 4.99 & 28.00 & 195.48 \\
\hline MTB & 2.93 & 3.17 & 3.65 & 3.30 & 2.17 & 1.25 \\
\hline Total assets & 1.05 & 0.39 & 1.90 & 0.57 & 10.98 & 222.73 \\
\hline Revenues & 0.00 & 0.00 & 0.67 & 0.00 & 9.40 & 173.43 \\
\hline \multicolumn{7}{|c|}{ Panel B Non-venture capital backed issuers } \\
\hline Number & 1963 & 1071 & 425 & 1496 & 383 & 84 \\
\hline Gross proceeds & 1.00 & 0.53 & 1.25 & 0.68 & 7.20 & 71.10 \\
\hline Net earnings & -0.06 & -0.07 & -0.33 & -0.10 & 0.68 & 8.71 \\
\hline Market cap. & 6.60 & 3.21 & 9.73 & 4.39 & 22.91 & 188.08 \\
\hline MTB & 2.97 & 3.18 & 3.93 & 3.34 & 2.27 & 1.23 \\
\hline Total assets & 0.86 & 0.37 & 1.38 & 0.51 & 10.05 & 233.42 \\
\hline Revenues & 0.00 & 0.00 & 0.42 & 0.00 & 7.60 & 156.92 \\
\hline \multicolumn{7}{|c|}{ Panel C Venture capital-backed issuers } \\
\hline Number & 182 & 29 & 80 & 109 & 58 & 15 \\
\hline Gross proceeds & 25.00 & 22.20 & 25.01 & 25.00 & 17.39 & 65.03 \\
\hline Net earnings & -0.26 & -1.08 & -2.14 & -1.94 & 1.28 & 6.99 \\
\hline Market cap. & 90.66 & 113.96 & 90.66 & 90.80 & 58.57 & 309.14 \\
\hline MTB & 2.42 & 2.70 & 2.78 & 2.75 & 2.04 & 1.39 \\
\hline Total assets & 18.84 & 7.86 & 17.78 & 15.08 & 19.35 & 185.04 \\
\hline Revenues & 8.61 & 0.00 & 3.08 & 1.22 & 18.39 & 200.36 \\
\hline
\end{tabular}

All amounts are median. All amounts are in millions of dollars (except number and MTB). Market cap. means post-issue market capitalization. MTB means market-to-book ratio measured as postissue market capitalization/(pre-IPO book value of equity + gross proceeds). Total assets is pre-IPO total assets. Revenues means pre-IPO total revenues. GROUP3 means small profitable issuers i.e. reporting pre-IPO positive earnings before non-recurring and extraordinary items with a pre-IPO shareholders' equity lower than \$M25. GROUP4 means large profitable issuers, i.e. reporting preIPO positive earnings before non-recurring and extraordinary items with a pre-IPO shareholders' equity higher than $\$ \mathrm{M} 25$. 
Table 5 Buy and hold abnormal returns (BHAR) of initial public offering (IPO) firms in Canada between 1986 and 2012. The benchmarks are respectively the BMO Small Cap and the S\&P/TSX. Mean BHAR are measured for the 36 months after the issue, using the market price or the issue price as the starting point. EW (VW) means equally weighted (value-weighted). $\mathrm{N}$ means number of observations. Earnings means earnings before non-recurring and extraordinary items. Small (large) profitable issuers report pre-IPO shareholders' equity lower (higher) than \$25 million. Value under each BHAR is Student's t test value.

\begin{tabular}{|c|c|c|c|c|c|c|}
\hline & \multicolumn{3}{|c|}{ BHAR, BMO Small Cap } & \multicolumn{2}{|c|}{ BHAR, S\&P/TSX } & \multirow[b]{2}{*}{ VW, \% } \\
\hline & $\mathrm{N}$ & EW, \% & VW, \% & $\mathrm{N}$ & $\mathrm{EW}, \%$ & \\
\hline \multicolumn{7}{|c|}{ Panel A Whole sample } \\
\hline \multirow[t]{2}{*}{ Market price } & 2145 & -27.59 & -8.80 & 2145 & -42.26 & -20.34 \\
\hline & & -15.83 & -4.63 & & -23.23 & -10.77 \\
\hline \multirow[t]{2}{*}{ Issue price } & 2145 & -13.74 & 2.94 & 2145 & -32.85 & -9.90 \\
\hline & & -6.25 & 1.31 & & -14.91 & -4.55 \\
\hline \multicolumn{7}{|c|}{ Panel B GROUP1 Issuers reporting no revenues } \\
\hline \multirow[t]{2}{*}{ Market price } & 1100 & -31.36 & -14.09 & 1100 & -46.66 & -29.51 \\
\hline & & -13.55 & -5.66 & & -19.14 & -11.12 \\
\hline \multirow[t]{2}{*}{ Issue price } & 1100 & -14.53 & -2.44 & 1100 & -35.38 & -21.37 \\
\hline & & -4.79 & -0.84 & & -11.59 & -7.17 \\
\hline \multicolumn{7}{|c|}{ Panel C GROUP2 Issuers reporting revenues and negative earnings } \\
\hline \multirow[t]{2}{*}{ Market price } & 505 & -30.26 & -15.44 & 505 & -43.47 & -28.96 \\
\hline & & -7.84 & -3.95 & & -11.01 & -7.80 \\
\hline \multirow[t]{2}{*}{ Issue price } & 505 & -19.24 & -5.83 & 505 & -36.58 & -19.01 \\
\hline & & -4.11 & -0.46 & & -7.93 & -1.59 \\
\hline \multicolumn{7}{|c|}{ Panel D GROUP3 Small profitable issuers } \\
\hline \multirow[t]{2}{*}{ Market price } & 441 & -23.95 & -23.94 & 441 & -39.30 & -34.48 \\
\hline & & -6.37 & -6.55 & & -9.96 & -9.41 \\
\hline \multirow[t]{2}{*}{ Issue price } & 441 & -13.38 & -11.20 & 441 & -31.38 & -22.62 \\
\hline & & -2.82 & -2.51 & & -6.60 & -5.12 \\
\hline \multicolumn{7}{|c|}{ Panel E GROUP4 Large profitable issuers } \\
\hline \multirow[t]{2}{*}{ Market price } & 99 & 11.77 & 8.53 & 99 & -0.41 & -0.26 \\
\hline & & 1.32 & 0.93 & & -0.04 & -0.03 \\
\hline \multirow[t]{2}{*}{ Issue price } & 99 & 21.57 & 21.59 & 99 & 7.76 & 10.71 \\
\hline & & 2.11 & 2.03 & & 0.74 & 1.04 \\
\hline \multicolumn{7}{|l|}{ Panel F TSX } \\
\hline \multirow[t]{2}{*}{ Market price } & 597 & -14.74 & -6.09 & 597 & -29.69 & -17.46 \\
\hline & & -4.28 & -1.73 & & -8.31 & -5.00 \\
\hline \multirow[t]{2}{*}{ Issue price } & 597 & -5.53 & 4.72 & 597 & -22.50 & -7.65 \\
\hline & & -1.35 & 1.15 & & -5.47 & -1.91 \\
\hline \multicolumn{7}{|l|}{ Panel G TSXV } \\
\hline \multirow[t]{2}{*}{ Market price } & 1548 & -32.54 & -32.97 & 1548 & -47.11 & -46.11 \\
\hline & & -16.25 & -15.81 & & -22.46 & -13.21 \\
\hline \multirow[t]{2}{*}{ Issue price } & 1548 & -16.90 & -13.01 & 1548 & -36.84 & -29.94 \\
\hline & & -6.49 & -4.78 & & -14.16 & -11.08 \\
\hline
\end{tabular}


Figure 3 Buy and hold abnormal returns (BHAR) of the whole sample of 2,145 initial public offering (IPO) firms in Canada between 1986 and 2012 by group of issuers. BHARs are expressed in percentage terms and are measured for the 36 months after the issue using the market price as the starting point. The benchmark is the BMO Small Cap. GROUP1 means issuers reporting no revenues in the prospectus. GROUP2 means issuers reporting revenues and negative earnings before non-recurring and extraordinary items. GROUP3 means small profitable issuers. GROUP4 means large profitable issuers. Small (large) issuers report pre-IPO shareholders' equity lower (higher) than \$25 million.

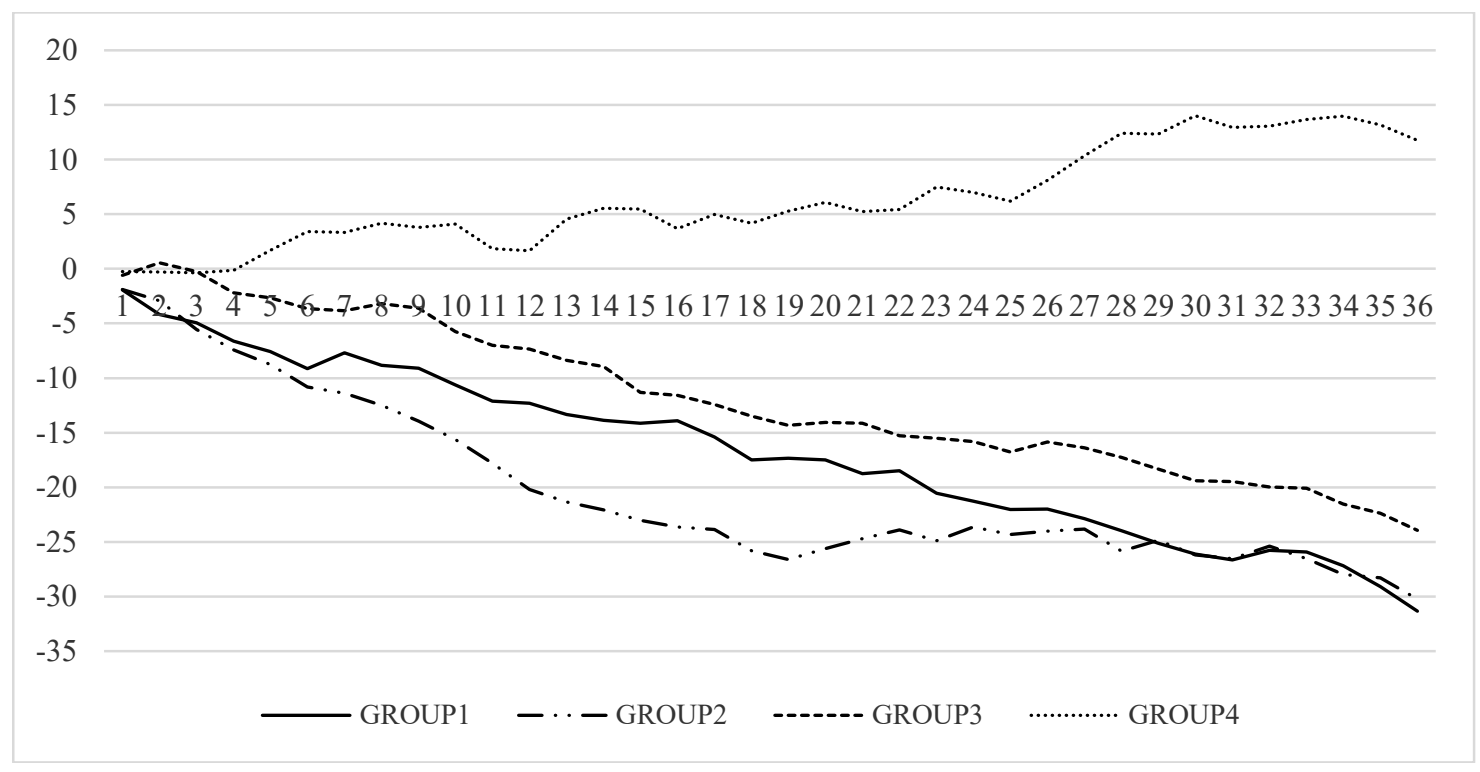


Table 6 Buy and hold abnormal returns (BHAR) of initial public offering (IPO) firms in Canada between 1986 and 2012 by stock exchange and decade. The benchmarks are respectively the BMO Small Cap and the S\&P/TSX. Mean BHAR are measured for the 36 months after the issue, using the market price or the issue price as the starting point. EW (VW) means equally weighted (valueweighted). $\mathrm{N}$ means number of observations. Earnings means earnings before non-recurring and extraordinary items. Value under each BHAR is Student's t test value.

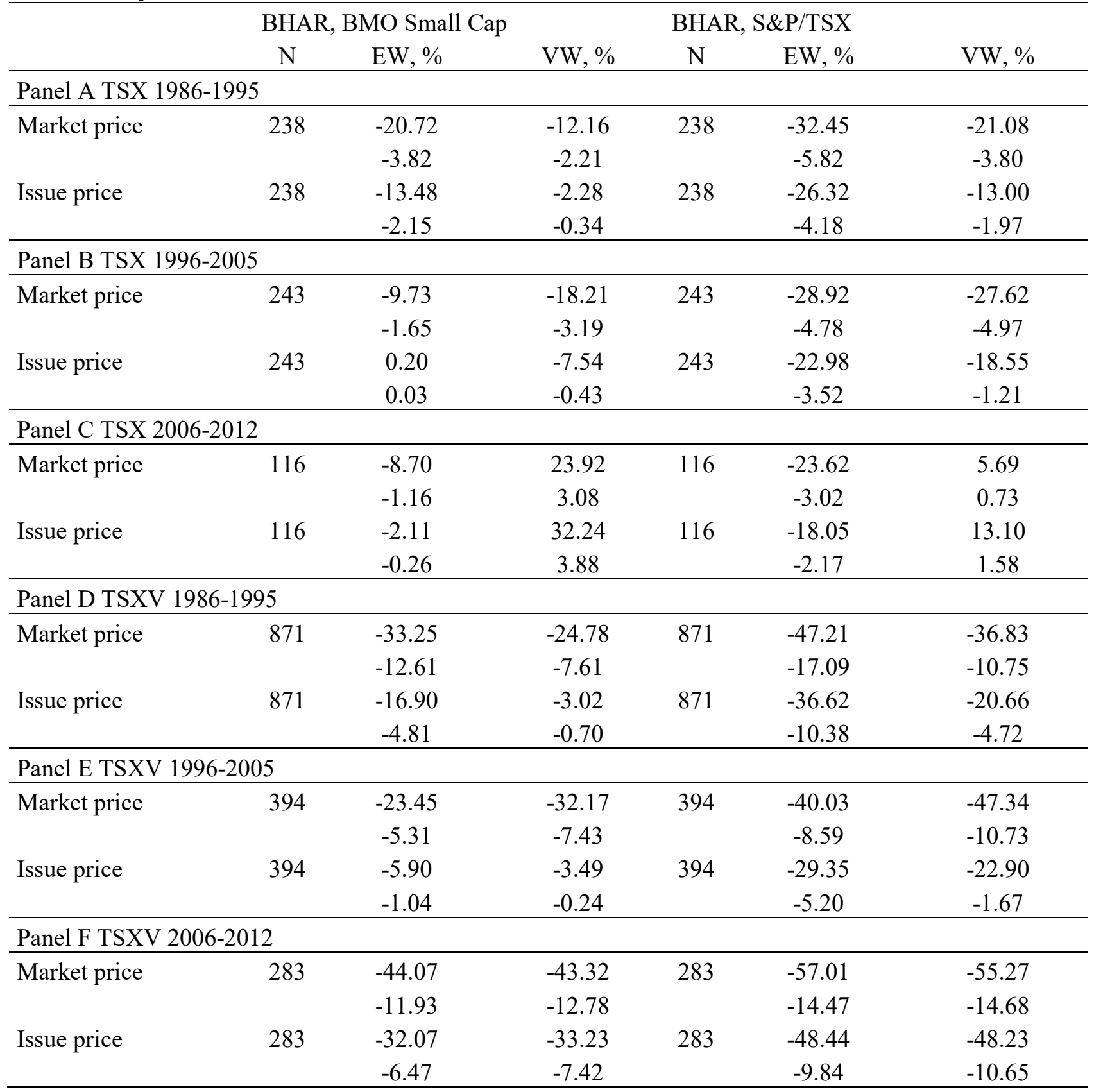


Table 7 Distribution of the buy and hold abnormal returns (BHAR) of 2,145 initial public offering (IPO) firms in Canada between 1986 and 2012 by GROUP. The benchmarks are respectively the BMO Small Cap and the S\&P/TSX. BHARs are measured for the 36 months after the issue, using the market price as the starting point.

\begin{tabular}{|c|c|c|c|c|c|}
\hline & $\begin{array}{c}\text { Whole sample } \\
\%\end{array}$ & $\begin{array}{c}\text { GROUP1 } \\
\% \\
\end{array}$ & $\begin{array}{c}\text { GROUP2 } \\
\% \\
\end{array}$ & $\begin{array}{c}\text { GROUP3 } \\
\% \\
\end{array}$ & $\begin{array}{c}\text { GROUP4 } \\
\% \\
\end{array}$ \\
\hline \multicolumn{6}{|c|}{ Panel A BHAR (r) using the BMO Small Cap as a benchmark } \\
\hline $\mathrm{r}<-100 \%$ & 11.10 & 9.64 & 16.04 & 10.66 & 4.04 \\
\hline$[-100 \%-50 \%]$ & 41.77 & 45.36 & 42.18 & 36.73 & 22.22 \\
\hline$[-50 \% 0 \%]$ & 22.14 & 23.09 & 16.24 & 24.49 & 31.31 \\
\hline$\left[\begin{array}{ll}0 \% & 50 \%\end{array}\right]$ & 10.40 & 9.00 & 9.70 & 13.83 & 14.14 \\
\hline$[50 \% 100 \%]$ & 4.76 & 3.64 & 5.35 & 5.67 & 10.10 \\
\hline $\mathrm{r}>=100 \%$ & 9.84 & 9.27 & 10.50 & 8.62 & 18.18 \\
\hline Total & 100.00 & 100.00 & 100.00 & 100.00 & 100.00 \\
\hline Negative earnings & 75.01 & 78.09 & 74.46 & 71.88 & 57.58 \\
\hline Skewness & 1.48 & 1.65 & 1.43 & 1.38 & 0.89 \\
\hline Shapiro-Wilk & & 0.81 & 0.81 & 0.86 & 0.89 \\
\hline $\mathrm{p}$ value & & $<0.0001$ & $<0.0001$ & $<0.0001$ & $<0.0001$ \\
\hline \multicolumn{6}{|c|}{ Panel B BHAR (r) using the S\&P/TSX as a benchmark } \\
\hline $\mathrm{r}<-100 \%$ & 23.73 & 25.00 & 26.53 & 20.63 & 9.09 \\
\hline$[-100 \%-50 \%]$ & 39.11 & 40.09 & 39.01 & 39.23 & 28.28 \\
\hline$[-50 \% 0 \%]$ & 15.71 & 16.00 & 11.68 & 17.23 & 26.26 \\
\hline$\left[\begin{array}{ll}0 \% & 50 \%\end{array}\right]$ & 8.21 & 6.36 & 9.31 & 10.20 & 14.14 \\
\hline$\left[\begin{array}{lll}50 \% & 100 \%\end{array}\right]$ & 4.48 & 4.73 & 3.96 & 4.08 & 6.06 \\
\hline $\mathrm{r}>100 \%$ & 8.76 & 7.82 & 9.50 & 8.62 & 16.16 \\
\hline Total & 100.00 & 100.00 & 100.00 & 100.00 & 100.00 \\
\hline Negative earnings & 78.55 & 81.09 & 77.23 & 77.10 & 63.64 \\
\hline Skewness & 1.52 & 1.65 & 1.48 & 1.45 & 0.97 \\
\hline Shapiro-Wilk & & 0.80 & 0.81 & 0.84 & 0.88 \\
\hline $\mathrm{p}$ value & & $<0.0001$ & $<0.0001$ & $<0.0001$ & $<0.0001$ \\
\hline
\end{tabular}

GROUP1 means issuers reporting no revenues before the IPO (in the prospectus). GROUP2 means issuers reporting revenues and negative earnings before non-recurring and extraordinary items. GROUP1-2 means issuers reporting negative earnings before non-recurring and extraordinary items (GROUP1 and GROUP2 together). GROUP3 (GROUP4) means small (large) profitable issuers, i.e. those reporting positive earnings before non-recurring and extraordinary items in the prospectus with a pre-IPO shareholders' equity lower (higher) than $\$ 25$ million. P value means p value of the ShapiroWilk normality test. 
Figure 4 Distribution of the buy and hold abnormal returns (BHAR) of the whole sample of 2,145 initial public offering firms in Canada between 1986 and 2012. The benchmark is the BMO Small Cap. BHARs are measured for the 36 months after the issue using the market price as the starting point.

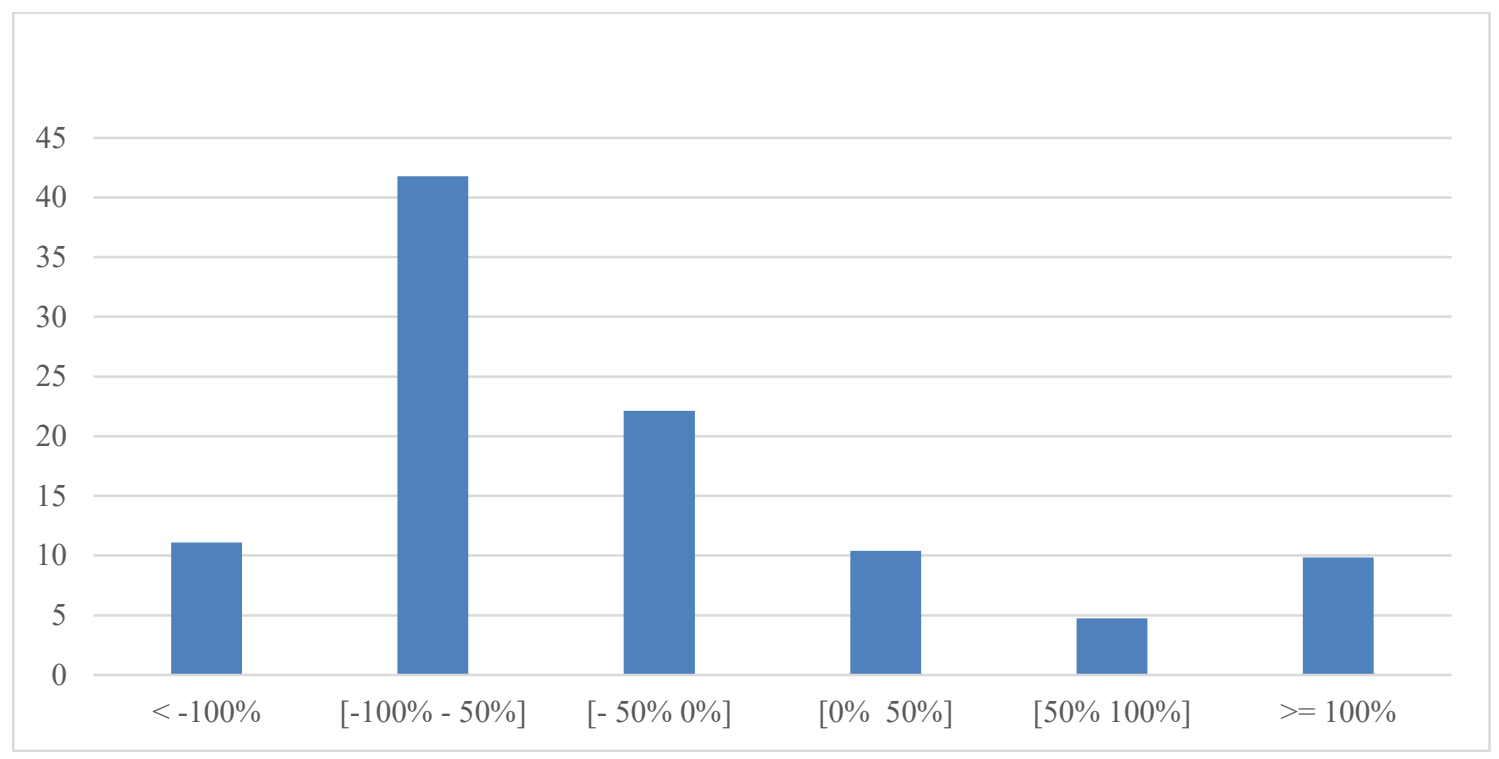


Table 8 Determinants of the buy and hold abnormal returns (BHAR) following the initial public offerings (IPOs). The dependent variable is the estimated BHAR over the 36 months following the issue using the market price as a starting point. The benchmarks are respectively the BMO Small Cap and the S\&P/TSX.

\begin{tabular}{lrrrr}
\hline & S\&P/TSX & BMO Small Cap & S\&P/TSX & BMO Small Cap \\
\hline Intercept & -0.6467 & -0.4814 & -0.6489 & -0.4840 \\
LMcap & $304.40 * * *$ & $184.85 * * *$ & $309.65 * * *$ & $189.22 * * *$ \\
DNR & 0.0136 & 0.0092 & 0.0093 & 0.0047 \\
& $3.62 *$ & 1.79 & 1.61 & 0.46 \\
GROUP1 & -0.0198 & -0.0091 & -0.0168 & -0.0062 \\
GROUP2 & 0.42 & 0.10 & 0.31 & 0.05 \\
& -0.0573 & -0.0583 & -0.0539 & -0.0547 \\
GROUP4 & 2.29 & 2.61 & 2.04 & 2.31 \\
& -0.0984 & -0.1347 & -0.1017 & -0.1387 \\
DHOT & $7.22 * * *$ & $14.84 * * *$ & $7.79 * * *$ & $15.93 * * *$ \\
& 0.2828 & 0.2673 & 0.2887 & 0.2729 \\
DCOLD & $19.42 * * *$ & $19.01 * * *$ & $20.42 * * *$ & $20.03 * * *$ \\
& -0.0365 & 0.0067 & -0.0352 & 0.0081 \\
DVCBIPO & 1.70 & 0.06 & 1.60 & 0.09 \\
Number & 0.1186 & -0.0725 & 0.1149 & -0.0754 \\
R square & $3.96 * *$ & 1.62 & $3.75 *$ & 1.78 \\
\hline
\end{tabular}

***,**** denote statistical significance at $1 \%, 5 \%$ and $10 \%$ respectively. We use the robust regression model with Huber M-estimation described in section 3.4. The dependent variable is the BHAR $\mathrm{i}_{1,1}$ to 36. LMcap is $\log$ of the post-IPO market capitalization, measured at the end of the issue month. DNR is a Dummy variable set to 1 if the firm operates in oil and gas or mining sectors, and 0 otherwise. GROUP1 means issuers reporting no revenues before the IPO (in the prospectus). GROUP2 means issuers reporting revenues and negative earnings before non-recurring and extraordinary items before the IPO. GROUP4 means large profitable issuers. i.e. those reporting pre-IPO positive earnings before non-recurring and extraordinary items with a pre-IPO shareholders' equity higher than $\$ 25$ million. DHOT (DCOLD) is a dummy variable set to 1 if the period is hot (cold) and 0 otherwise. DVCBIPO is a dummy variable set to 1 if a venture capitalist is involved and 0 otherwise. The value under each parameter is Chi Square. 